\title{
THE REACTIONS OF (+)-2- AND (+)-3-CARENES WITH THE RETENTION OF THE BICYCLIC FRAMEWORK
}

\author{
Liudmila Bets, Liudmila Vlad, Fliur Macaev* \\ Institute of Chemistry of the Academy of Sciences of Moldova, \\ Academy str. 3, MD-2028, Chisinau, Moldova \\ Tel +373-22-739-754, Fax+373-22-739-954, E-mail: flmacaev@cc.acad.md
}

\begin{abstract}
Carane-type compounds have attracted attention in recent years due to their practical importance. This review is focused on describing the developments in the synthesis of trimethylbicyclo[4.1.0]heptanes and their unsaturated analogues from monoterpenes $(+)-2$ - and $(+)-3$-carenes published mostly during the last decade.
\end{abstract}

Keywords: $(+)$-2- carene, $(+)-3$-carene, trimethylbicyclo[4.1.0]heptanes, trimethylbicyclo[4.1.0]hept-3-enes, organic synthesis.

\section{Introduction}

Progress of modern synthetic organic chemistry is determined by two general tendencies - profound study of biological processes and natural products as the ground for the creation of new effective bioregulators (drugs, pharmaceuticals, diagnostic materials, pesticides et al.) and the use of natural substances as the starting materials (raw materials) for the synthesis of new optically active compounds including bioregulators. The development of new enantiopure compounds, in particular new medicals having chiral centers in a molecule (such substances are found in

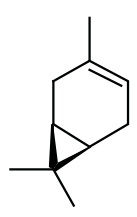

1a

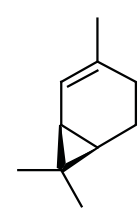

$1 \mathrm{~b}$ about, the third part of all drugs and in more than $75 \%$ of new pharmaceuticals) is connected with the requirements of obtaining high molecular purity. It is well known that one of the tasks of the synthesis of a bioactive compound is the preparation of the required enantiomer in an optically pure form. Bicyclic monoterpenes (+)-3-carene $\mathbf{1 a}$ and (+)-2-carene $\mathbf{1 b}$ are widely used for resolving this type of problems [1-7]. A structural feature of both compounds is the presence of the reactive $\mathrm{C}=\mathrm{C}$ double bond and bicyclic bridging system. This fact opens perspectives for a new synthesis with the retention of the bicyclic framework of monoterpenes $\mathbf{1} \mathbf{a}, \mathbf{b}$. The main attention in this review is focused on the articles published during the last decade, and on those not mentioned in the above references. Data on skeleton transformation as well as a gradual fragmentation of the terpenes framework are published in works [8-13] and will be not considered hereafter.

\section{Synthesis on the basis of (+)-3-carene with the retention of the carane framework}

Sulfur containing terpenoids derivatives, which have a number of important properties, are not found in nature. The regioselective method for obtaining epimeric sulfides 2 is described in [14] and it is based on the hydrolysis of the product of sulfenyl chloride addition to $(+)-3$-carene 1a (scheme 1).

\section{Scheme 1}

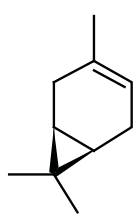

$1 \mathbf{a}$

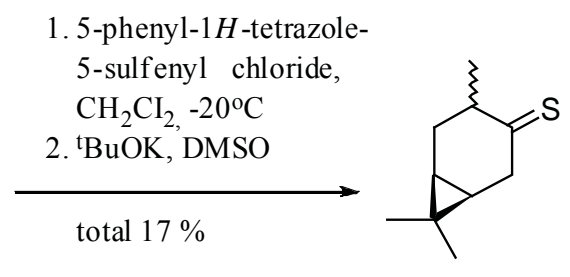

2

In order to perform the introduction of the thio-group into position 3 of the carane framework it is suggested to use the addition of $(\mathrm{MeS})_{2}$ to carene 1 a or thio-caranes $\mathbf{4 , 7}$ (scheme 2).

The $\mathrm{ZnCl}_{2}$ catalyzed addition of $(\mathrm{MeS})_{2}$ yields a mixture of isomeric products $\mathbf{6 a}, \mathbf{b}(\mathrm{R}=\mathrm{H})[15,16]$. For the synthesis of similarly built substances, the $\alpha$ - and $\beta$-thio-oxides of 3 -carene epoxides $\mathbf{3 a}$ and $\mathbf{3 b}$ have been prepared. The latter gave the carane derivatives $\mathbf{5}$ and $\mathbf{8}$ upon the interaction with mercaptans. The respective homologues $\mathbf{6 a}, \mathbf{b}(\mathrm{R}=\mathrm{Me}, \mathrm{Et}$, i-Pr or prenyl) are formed at alkylation of mercaptans in alkaline conditions with alkyl halides. 


\section{Scheme 2}

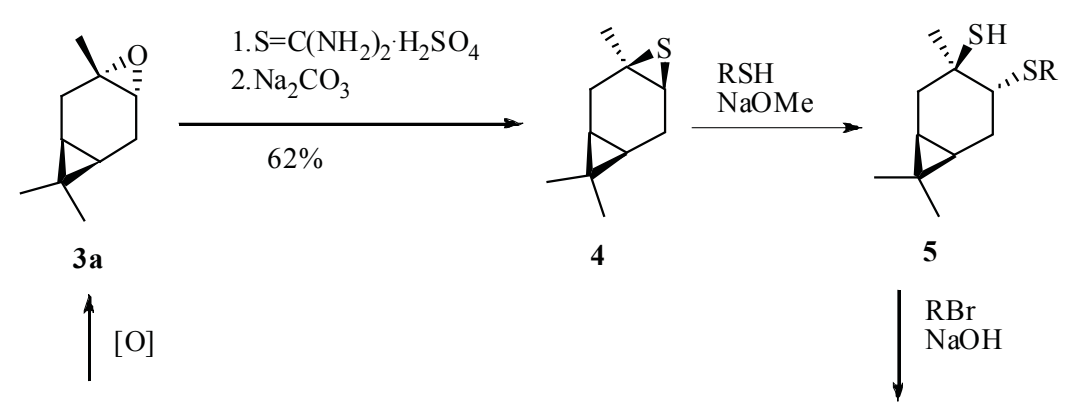<smiles>CC1=CCC2C(C1)C2(C)C</smiles>

1. NBS

2. $\mathrm{KOH}$

$70 \%$

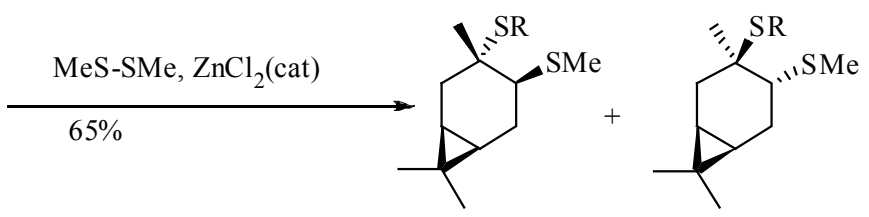

$6 a$

$6 \mathrm{~b}$

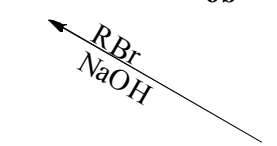<smiles>CC12CC3C(CC1O2)C3(C)C</smiles>

3b

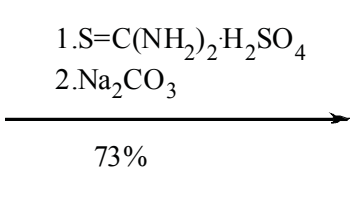

7

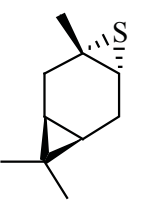

7

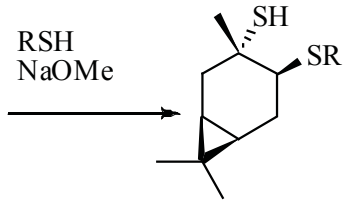

8

$\mathrm{R}=\mathrm{Me}, \mathrm{Et}, i-\operatorname{Pr}$, prenyl

Initial epoxides 3a can be obtained using peroxy acids, dimethyloxirane, by the oxidization with $\mathrm{H}_{2} \mathrm{O}_{2}$ or $\mathrm{O}_{2}$ catalyzed by transition metals [22-50]. One of the most used epoxidation methods is the stoichiometric peracid route using such acids as peracetic acid and $m$-chloroperbenzoic acid. The employment of peroxy acids is not a clean method as equivalent amounts of acid waste are produced. The safety issues associated with handling peracids are also a matter of concern. The use of hydrogen peroxide as a cheap, environmentally clean and easily handled oxidant in conjugation with robust and easily obtainable synthetic metalloporphirins, transition metal Schiff base complexes of various metals, heteropoly acids, transition metal substituted heteropoly acids as catalysts led to procedures, which help to perform epoxidation reaction. However, the chemo- and stereoselectivity of the oxidation reactions were not high. Moreover, the separation of the catalysts is usually troublesome and not economical for application. Dimethyldioxirane epoxidation of (+)-3-carene 1a gave the corresponding epoxide 3a (yield 100\%). In pilot conditions, carene 1a is oxidized into epoxide 3a (yield 93\%) by pinane hydroperoxide in the presence of molybdenum catalysts [51]. Epoxide $\mathbf{3 b}$ is synthesized in two steps with a $70 \%$ yield [52].

Synthesized tiocaranes as well as (+)-3-carene 1a itself show an antifungal activity [53].

Hydroxymercaptans and sulfides 9-12, that are of interest as physiologically active compounds and reagents, have been synthesized from epoxides $\mathbf{3 a}, \mathbf{b}[54,55]$ (scheme 3 ).

It has been established that the interaction of oxides $\mathbf{3 a}, \mathbf{b}$ with thioglycolic acid proceeds along with the formation of isomeric diols 10a,b in mixture with acids $\mathbf{9 a}, \mathbf{b}$. The given reactions allow the synthesis of disulfide $\mathbf{1 1}$ and enantiomers 12a,b. However, the yield of these products is low.

cis-Diol 13 can be synthesized by direct hydroxylation of 3-carene 1 with $\mathrm{KMnO}_{4}$ or $\mathrm{OsO}_{4}[56,57]$.

Salakhutdinov et al published the synthesis of compound $\mathbf{1 3}$ using cis-opening of epoxide 3a [58]. This approach gave cis-diol avoiding skeleton rearrangements, which were noticed with $\beta$-epoxide $\mathbf{3 b}$.

We designed and synthesized novel $P^{*}$-chiral monodentate phosphite ligands, having five-membered phosphacycles and OMe (or NEt ${ }_{2}$ ) exocyclic substituents (scheme 4) [59, 60].

These can be easily prepared by direct phosphorylation of the appropriate 13 and purified by vacuum distillation. Carene-based compounds $\mathbf{1 4 a}, \mathbf{b}$ are characterized by rather small contents of the minor epimer. The major stereoisomer has the $R$ - configuration at the $P^{*}$ - stereocenter. 
Scheme 3

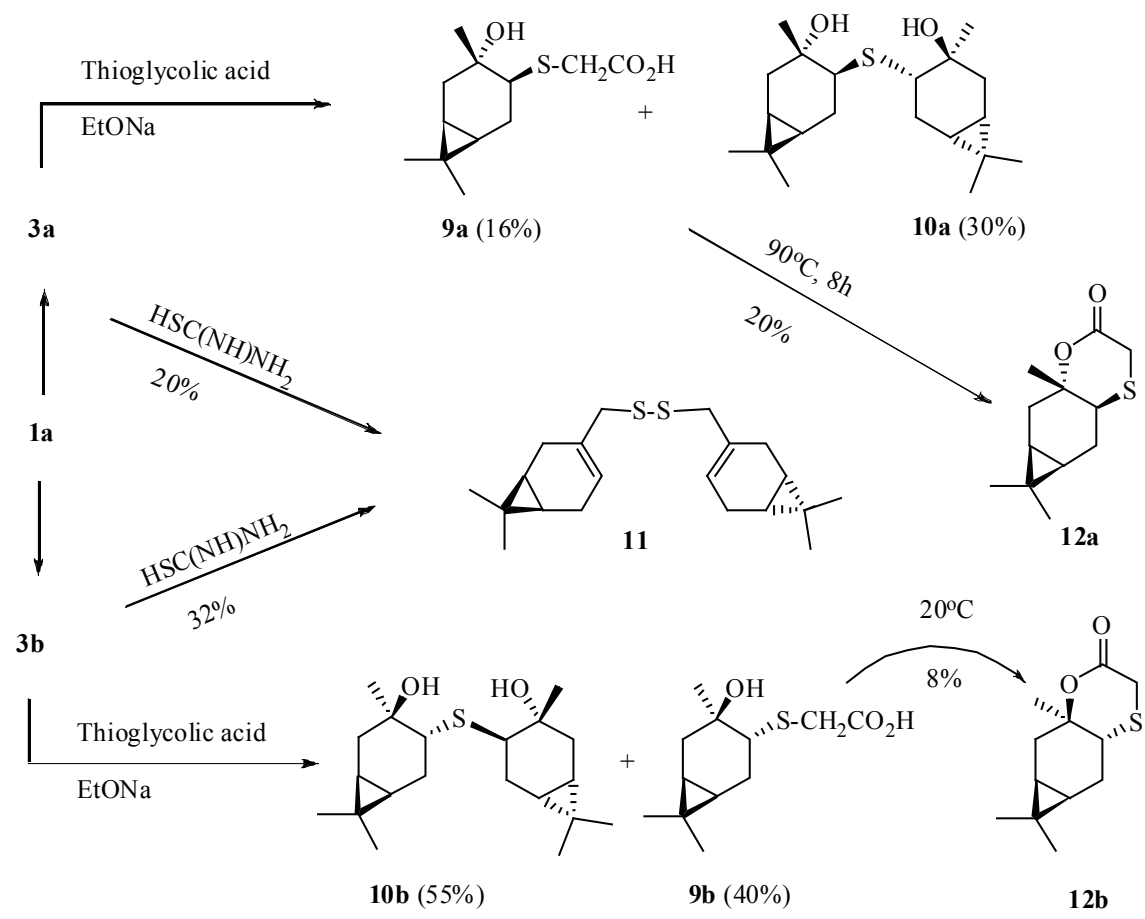

Scheme 4

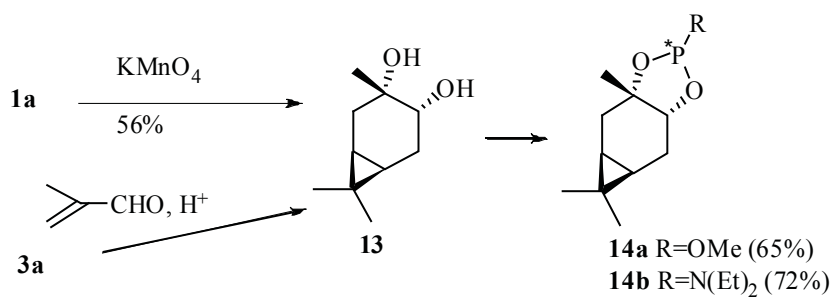

One of the approaches to enhance asymmetrising activity of chiral phosphite-type compounds is the synthesis of the respective $P, N$-bidentate ligands with additional $C^{*}$ - stereocenters in the side chain $N$-containing group. In particular, oxazolinophosphite $\mathbf{1 5}$ has been prepared using phosphoramidite $\mathbf{1 4 b}$ as a phosphorylating reagent (scheme 5).

\section{Scheme 5}
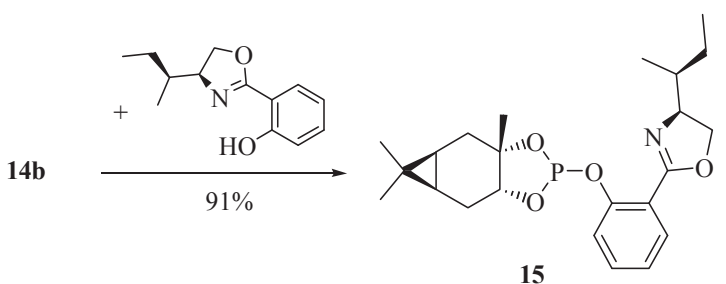

Using these novel ligands, up to $91 \%$ ee was achieved in the Pd-catalysed asymmetric allylic amination [59, 60].

$\beta$-Hydroxyamine 16, obtained by the interaction of epoxide 3a with morpholine [61-63], was an effective catalyst in addition of diethylzinc to aromatic aldehydes in the synthesis of optically active alcohols (up to $98 \%$ ee) (scheme 6). 


\section{Scheme 6}

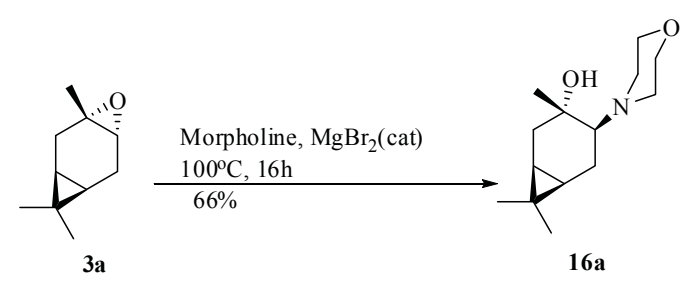

Diastereomeric compound $\mathbf{1 6 b}$ has been synthesized from epoxide $\mathbf{3 b}$ and morpholine [64] (scheme 7).

Scheme 7

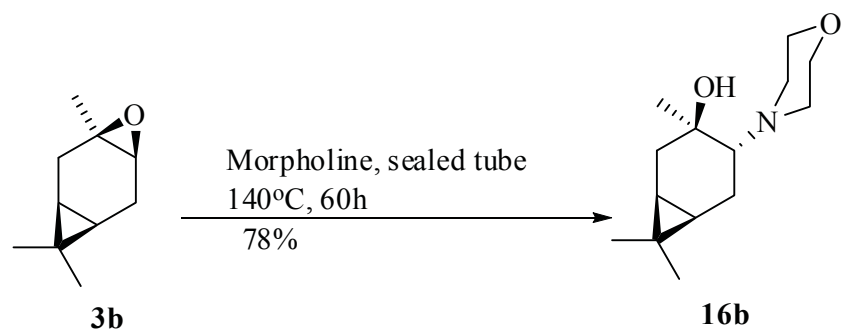

Another, no less interesting group of carane derivatives 7a-d, has been synthesized from oxide 3a,b (scheme 8). It should be noted that in most cases the syntheses are not selective, though they have been carried out in various proton solvents during catalysis with inorganic or organic acids, oxides of heavy metals, or under photolysis [57, 43, 65-77].

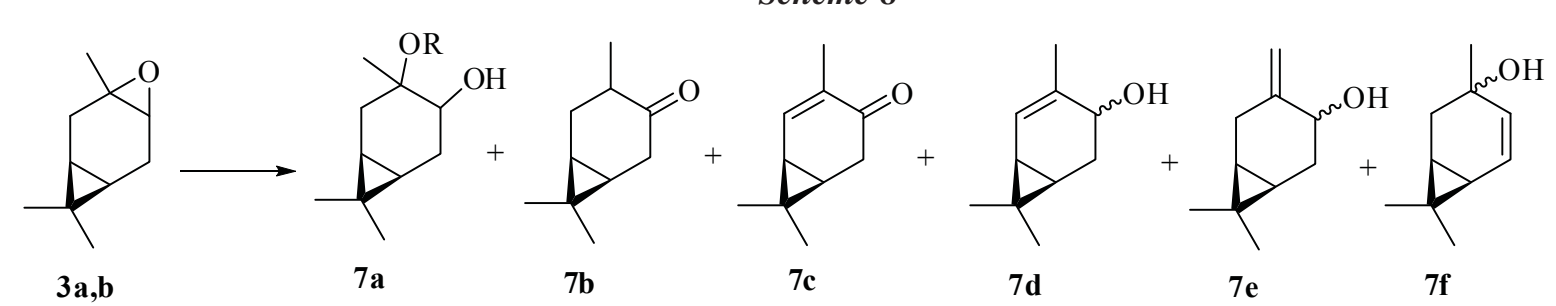

$$
\mathrm{R}=\mathrm{H}, \mathrm{Me}, \mathrm{Et}, \mathrm{Pr}
$$

Acid-catalysed opening of the epoxide 3a involves the cleavage of a more highly substituted C-O bond and affords as a rule compound 7a accompanied by trace amounts of the opposite 4-alkoxy-3-caranols. The treatment of oxide $\mathbf{3 a}$ with both mineral acids and acetic acid provides 4 -caranone $\mathbf{7 b}$. The rearrangement of epoxide $\mathbf{3 a}$ has been made using boron trifluoride etherate, which resulted in the mixture of the 4-caranone (43\%) with menth-3-en-2-one (28\%).<smiles>CC1=CCC2C(C1)C2(C)C</smiles>

$1 \mathrm{a}$

(a)

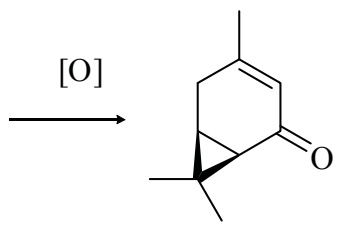

$8 a$<smiles>CC1=CC(=O)CC(C)(C)C=C1</smiles>

9b

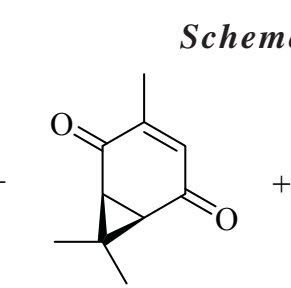

$8 b$<smiles>CC1=CC[C@@H]2C(C1=O)C2(C)C</smiles>

8c<smiles>CC1=C[C@H]2[C@@H](CC1=O)C2(C)C</smiles>

$7 \mathrm{c}$ 3a,b<smiles>CC1=CC[CH+]CC(C)(C)C1</smiles>

9a<smiles>[CH2-][C@@](C)(O)C1C=CC=C(C)C1</smiles>

9c<smiles>Cc1cccc(C(C)(O)[18F])c1</smiles>

9d<smiles>Cc1ccc(C(C)(C)O)cc1</smiles>

9e<smiles>CC1=CCC(C(C)(C)O)C=C1</smiles>

9f 
The treatment of the isomeric epoxide $\mathbf{3 b}$ under identical conditions provides product $7 \mathbf{b}$ with $66 \%$ yield. In contrast with the epoxide 3a, which gives major trans-diols $\mathbf{7 a}(\mathrm{R}=\mathrm{H})$ on the acid-catalyzed hydrolysis - epoxide $\mathbf{3 b}$ was noted to give both the expected cis- and trans-diols $7 \mathrm{a}(\mathrm{R}=\mathrm{H})$ in $26 \%$ and $53 \%$, respectively. The repetition of the experiment in acidic $\mathrm{MeOH}$ provides both regio-isomeric hydroxy ethers in total yield $80 \%$. The treatment of the isomeric epoxides $\mathbf{7 a , b}$ with oxides of heavy metals or under photosensitized conditions provides the mixture of isomeric carenes $7 \mathbf{c}-\mathbf{f}$.

Liquid-phase oxidative conversions of carene 1a are technologically perspective but it is difficult to make them, just like the previous ones, due to the low selectivity of the process, which results in a low yield and a difficult identification of the enones 8a-d, 9a,b, epoxides 3a,b, diene 9c and aromatic hydrocarbons 9d-f [78-80].

The introduction of functional groups in the $\mathrm{C} 4$ position of caranes is required for the elaboration of approaches to obtain practically important gem-dimethylcyclopropanes, e.g to fragrant substances [81-84]. $[85,86]$

Overall yield of 4-formylcarane 10 at hydroformylation or carbonylation has not exceeded $40 \%$ (scheme 10 )

\section{Scheme 10}

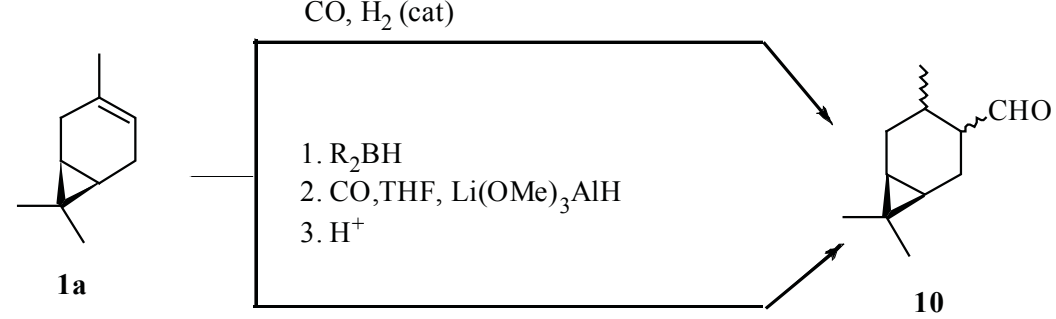

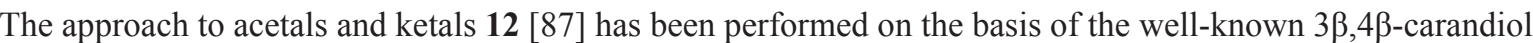
$11[76,88,89]$

\section{Scheme 11}

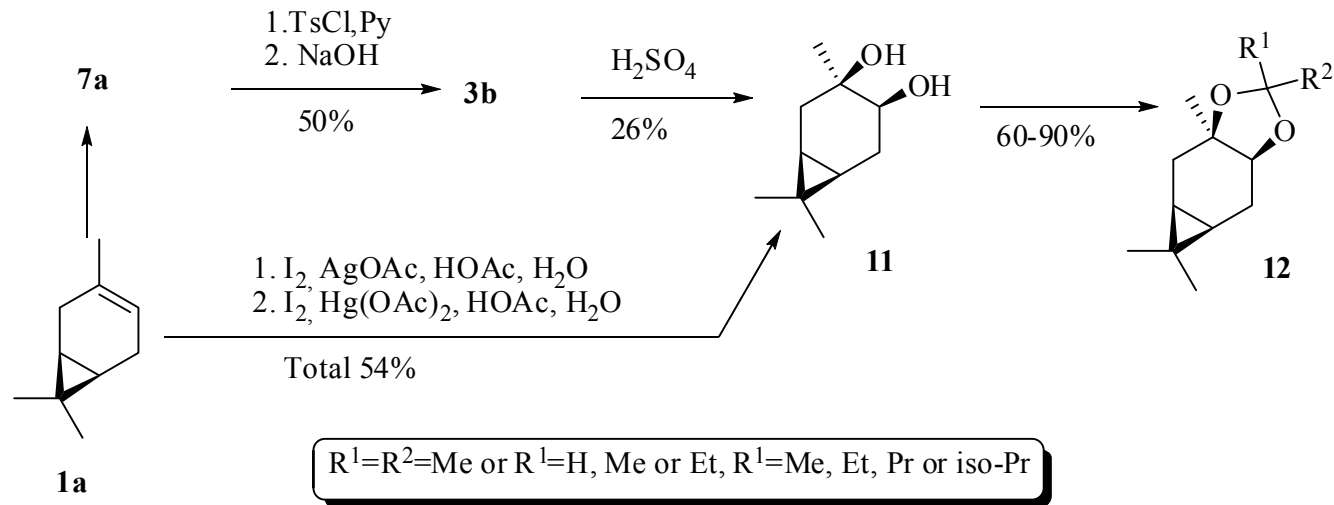

Target products have been obtained by the treatment of diol $\mathbf{1 1}$ and the corresponding aldehyde or ketone with catalytic amounts of sulfuric or $p$-toluenesulfonic acids. These acetals and ketals had odour characteristics and in these conditions the gem-dialkyl group created pleasant, floral-balsamic or floral-wood odours. Acetals had markedly less odour.

Odorants 14a-c have been synthesized from 4-hydroxy-3(10)-carene 13 (scheme 12) [ 90, 91].

Another group [92] has described the stereoselective route from an alcohol $\mathbf{1 3}$ to functionalized ketone 15, olefines 17, 20, and aldehyde 19.

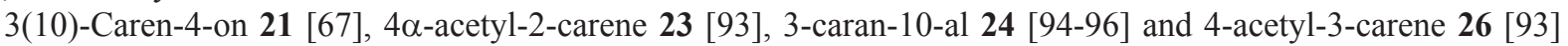
have been selected [97-99] for the construction of intermediates 22, 25, 27, 28 of the optically active tri- and tetracyclic analogues of sesquiterpenes from Nardostachys jatamansi and Aristolochia debilis [100], and the homologues of some crop protection agents (scheme 13) [5, 101- 103]. 


\section{Scheme 12}

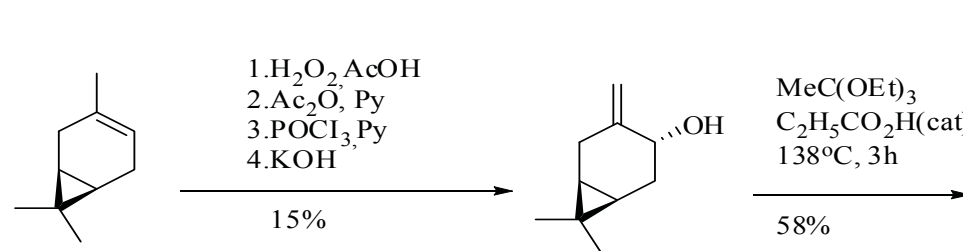

13

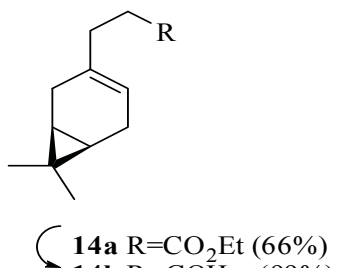

$\begin{cases}14 \mathrm{~b} \mathrm{R} & =\mathrm{COH} \quad(99 \%)\end{cases}$

14c $\mathrm{R}=\mathrm{COAc} \quad(73 \%)$

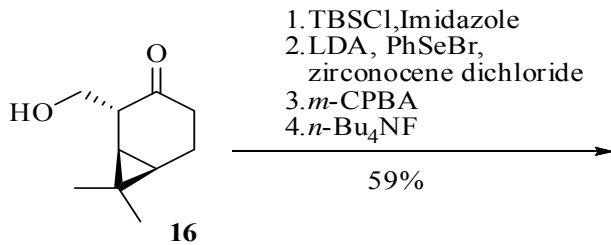

16
15

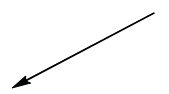

2.TMSCl,LHMDS 3.HCHO aq., Yb(OTf $)_{3}$ $62 \%$<smiles>CC1(C)[C@H]2CCC(=O)[C@@H](CO)[C@H]21</smiles>

17

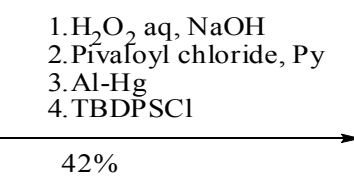

$42 \%$

$42 \%$

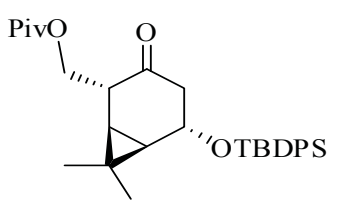

18

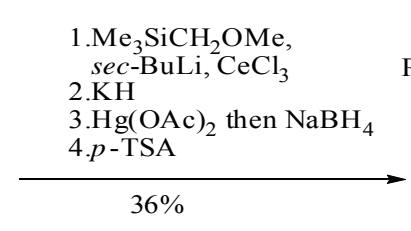

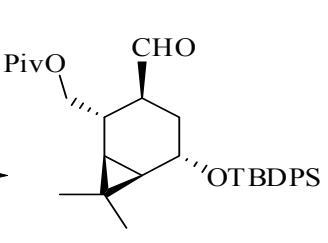

19

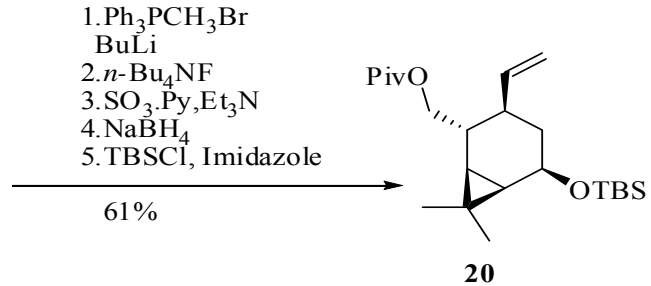

20

Scheme 13

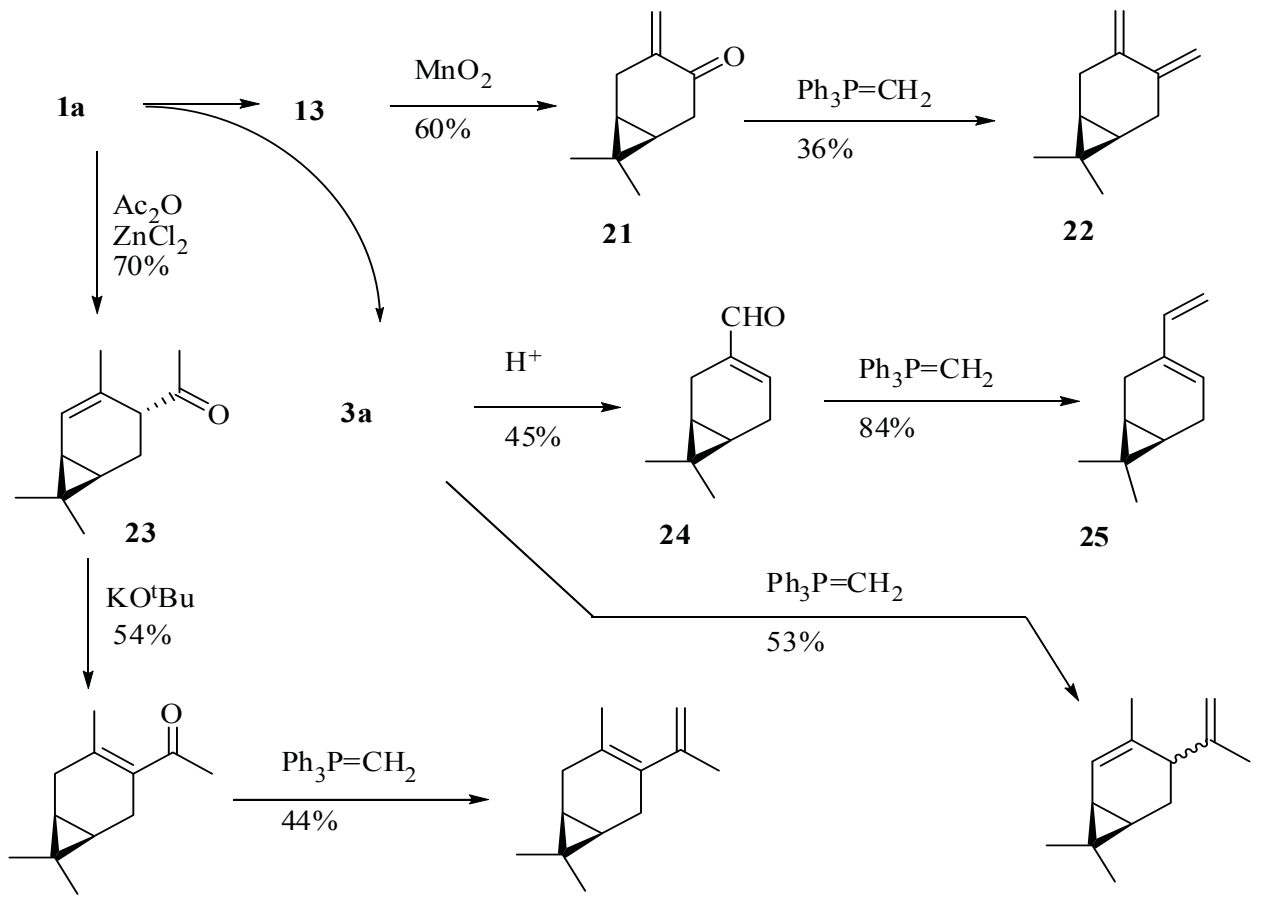

26

27 
The synthesis of cyclic products on the basis of compounds 22, 25-28 has been discussed in the review [6], so it will not be considered hereafter. $106]$

The direct amidocyclopropanation of (+)-3-carene 1a using organozinc carbenoids gives a single isomer 29 [104-

Scheme 14<smiles>CC1=CCC2C(C1)C2(C)C</smiles>

1a

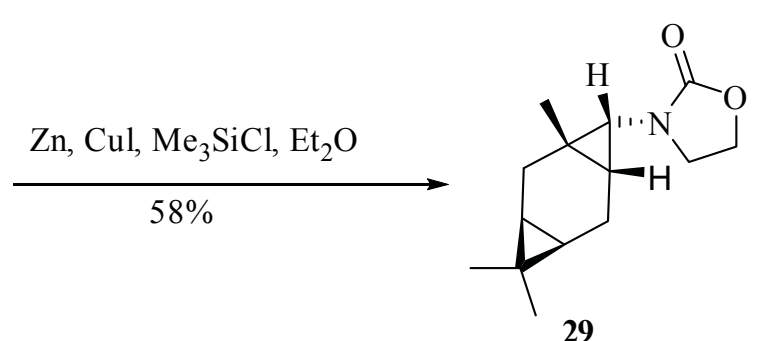

29 [107].

A pathway for preparing optically active lactam functionalized ionic liquid $\mathbf{3 1}$ was demonstrated by scheme 15

Scheme 15

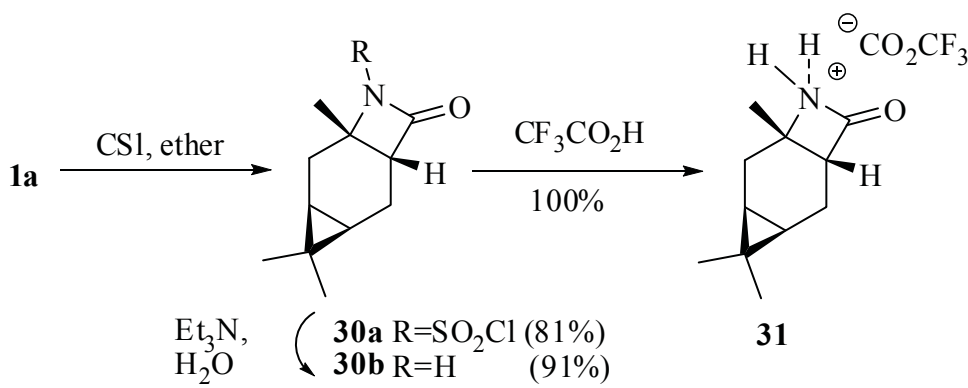

The reaction of chlorosulfonyl isocyanate addition to compound 1a proceeds regio- and stereoselectively with the formation of $\beta$-lactam 30a. The hydrolysis of compound 30a has yielded the product 30b [108].

The synthesis of lactams 34, 35 included the preliminary constructing of the diol 32a or the bromohydrine $\mathbf{3 2 b}$ with following cycloaddition of anhydrides 33a,b to imines (scheme 16) [109-111].

\section{Scheme 16}

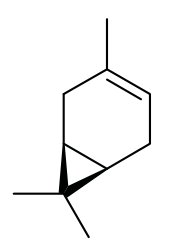

$1 \mathbf{a}$

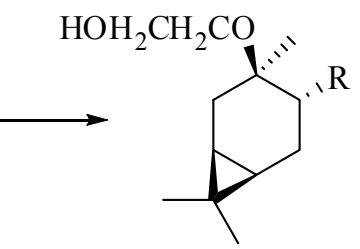

32a $\mathrm{R}=\mathrm{OH}$

32b $\mathrm{R}=\mathrm{Br}$

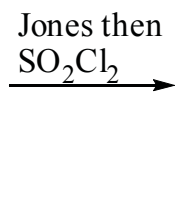

33a $\mathrm{R}=\mathrm{O}$

33b $\mathrm{R}=\mathrm{Br}$

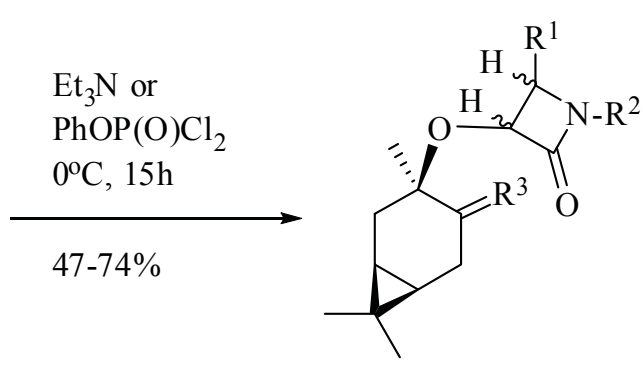

34
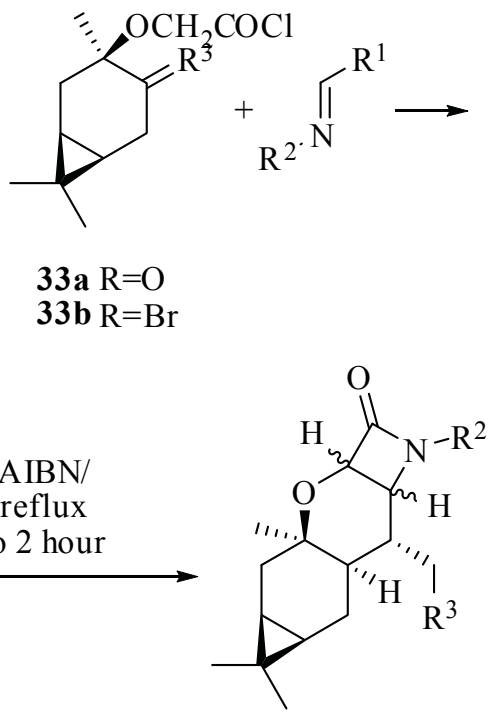

35

The ketoximes of the carane series should also be mentioned (scheme 17) [112, 115-120]. 


\section{Scheme 17}

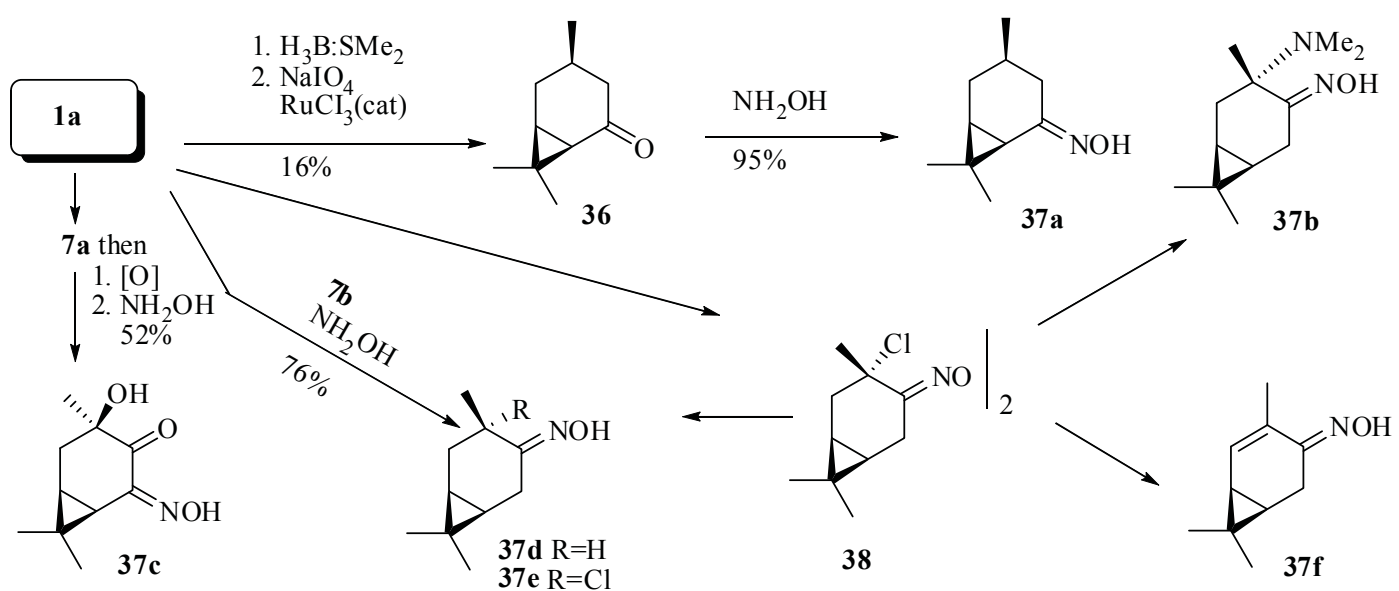

Substances $\mathbf{3 7 a , c , d ~ h a v e ~ b e e n ~ c l a s s i c a l l y ~ s y n t h e s i z e d ~ f r o m ~ k e t o n e s ~} \mathbf{7 b}$ and $\mathbf{3 6}$, while the homologues $\mathbf{3 7 b}, \mathbf{f}$ have been obtained on the basis of the adduct 38 .

Asymmetric ring opening of meso-epoxide with $B$-halobis(2-isocaranyl)boranes affords chlorohydrine $\mathbf{3 9}$ with $19 \%$ ee enantioselectivity (scheme 18) [121].

\section{Scheme 18}

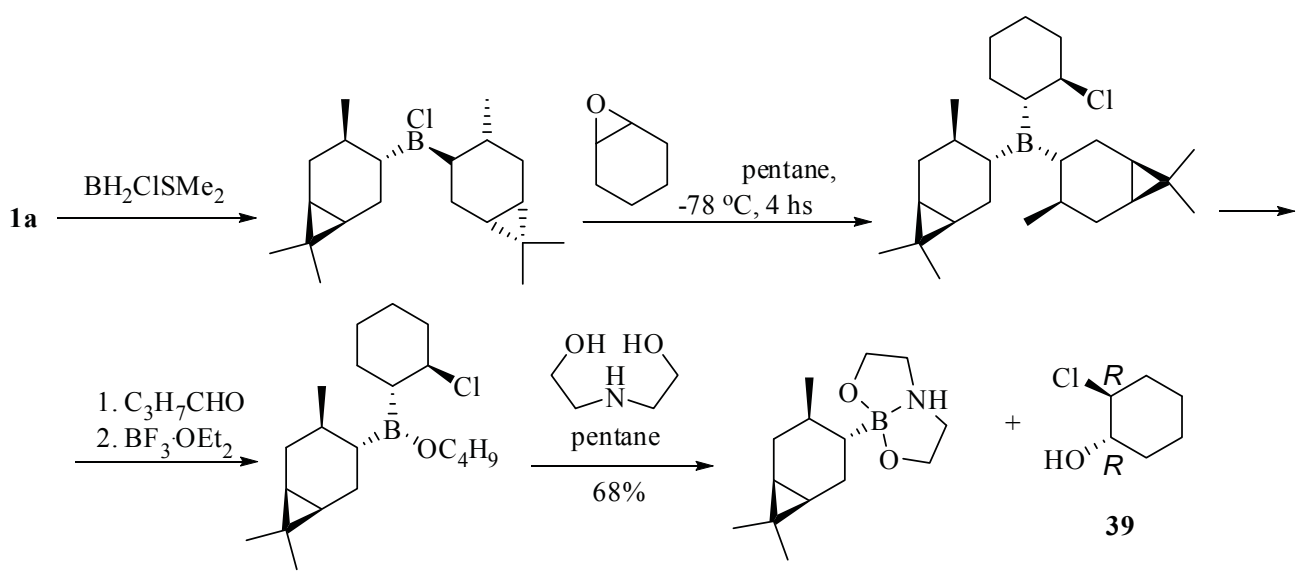

A convenient method for the syntesis of optically active trans-hydroxyselenodes $40 a-c, 43$ from oxide $3 \mathbf{a}$ on the reactions of sodium selenide or sodium diselenide was described (scheme 19) [122].

\section{Scheme 19}

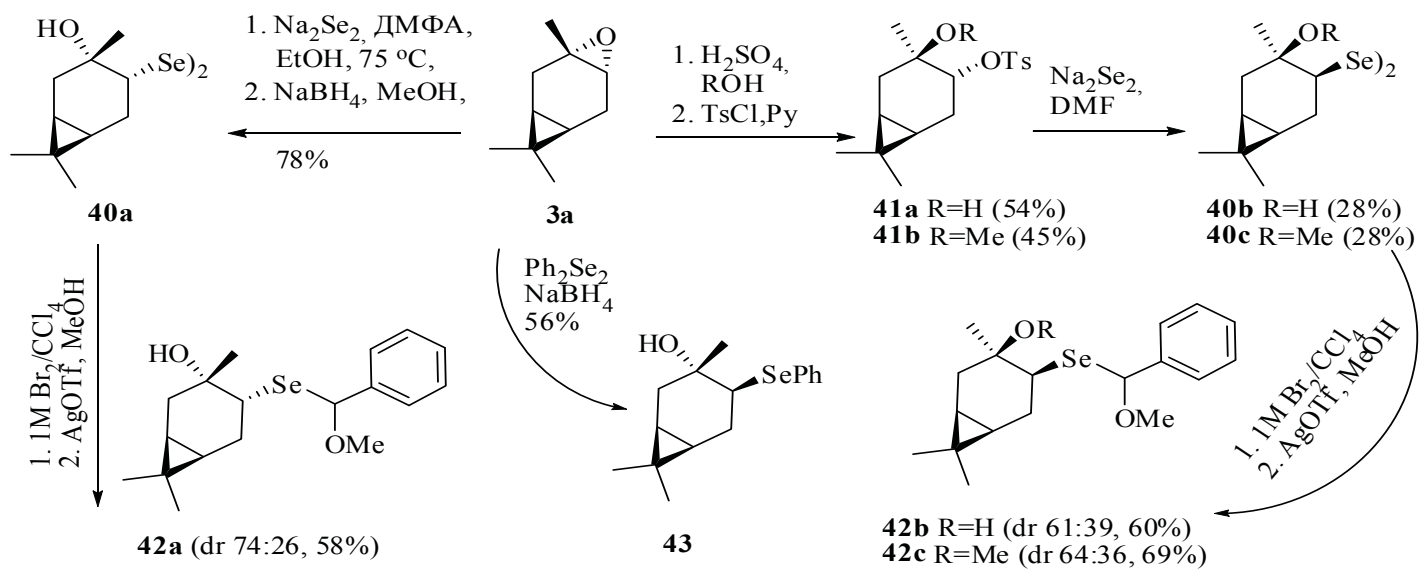


The cis-hydroxy and cis-methoxydiselenides $\mathbf{4 0 b}, \mathbf{c}$ were obtained in the reaction of sodium diselenide with the corresponding hydroxy- and methoxytosylates $\mathbf{4 1 a , b .}$

New chiral selenium-caranes $\mathbf{4 5 a , b}$ as well as $\mathbf{4 6 a}$,b can be synthesized from hydroxyselenide 44 [123].

Scheme 20

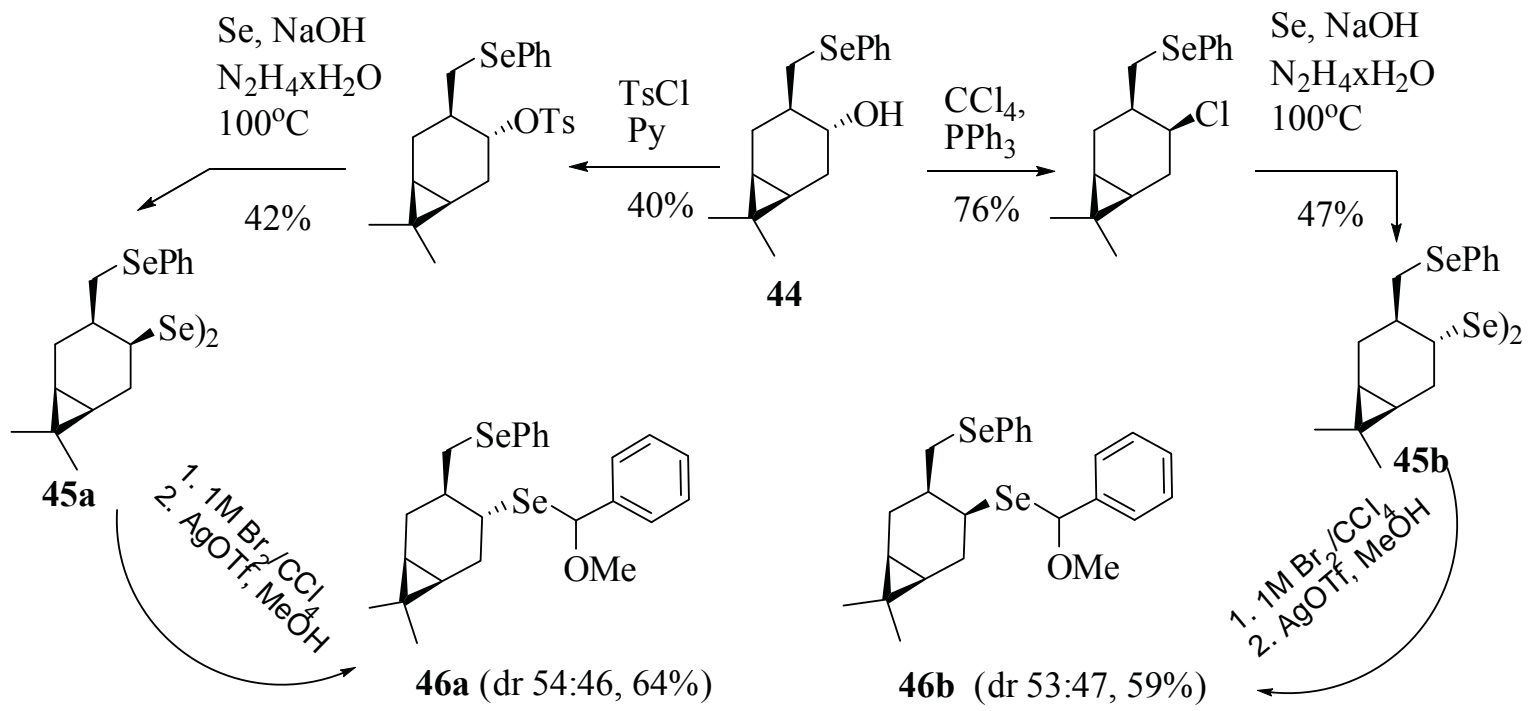

The diselenides were used for asymmetric selenenylation of sterene and selenocyclization with o-allylphenol with moderate yield but low diastereoselectivety.

$(+)$-3-Carene 1a has been easily converted into $\beta$-azidoselenide 47 by addition of PhSeOTf in the presence of $\mathrm{NaN}_{3}[123]$

Scheme 21

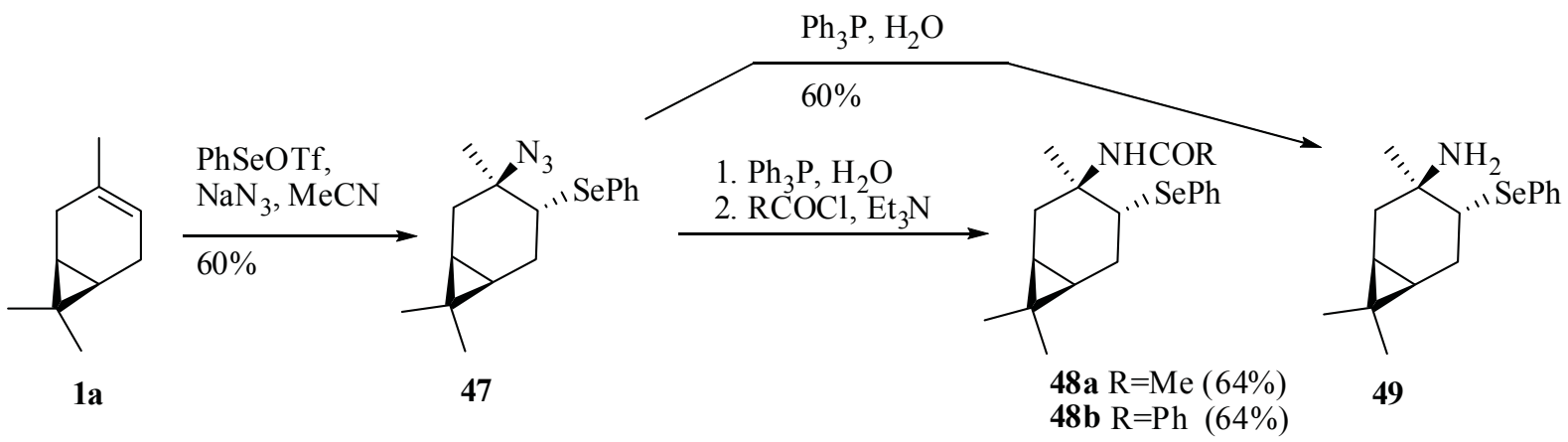

Using classical procedures, compound 47 was converted into amidoselenides $48 \mathbf{a}, \mathbf{b}$ and aminoselenide 49.

The regio- and stereoselective aminohydroxylation of monoterpene 1a into hydroxytoluenesulfonamide 47 was reported [124].

Scheme 22

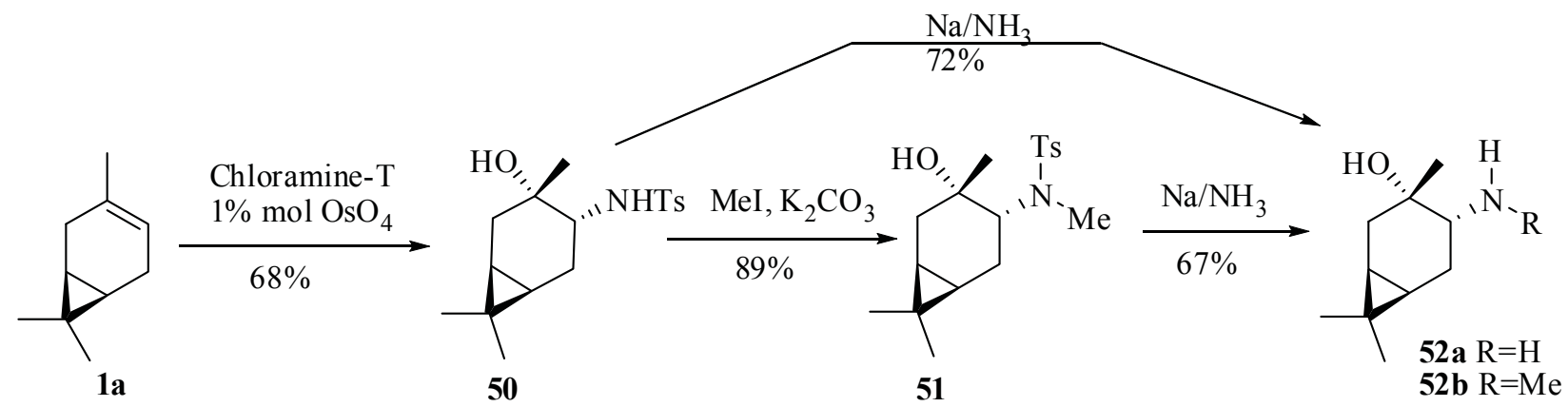


The methylation of compound $\mathbf{5 0}$ gives the corresponding product $\mathbf{5 1}$. The sulfonamides $\mathbf{5 0 , 5 1}$ were reduced with sodium in liquid ammonia to give the corresponding cis-amino alcohols $\mathbf{5 2 a}, \mathbf{b}$. [129].

The ionic-liquids 55a-c [125-128] catalyzed Kondakov and Prince reactions of monoterpene 1a were described

\section{Scheme 23}<smiles>CC1=CCC2C(C1)C2(C)C</smiles>

$1 \mathbf{a}$

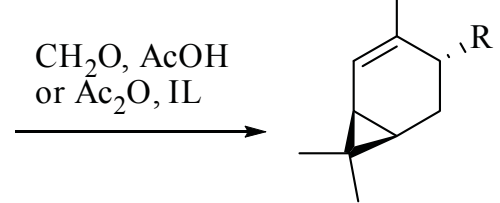

$23 \mathrm{R}=\mathrm{Ac}$

54a $\mathrm{R}=\mathrm{CH}_{2} \mathrm{OH}$

54c $\mathrm{R}=\mathrm{CH}_{2} \mathrm{Ac}$<smiles>[R]C1CC2C(C=C1C)C2(C)C</smiles>

$53 \mathrm{R}=\mathrm{Ac}$ 54b $\mathrm{R}=\mathrm{CH}_{2} \mathrm{OH}$

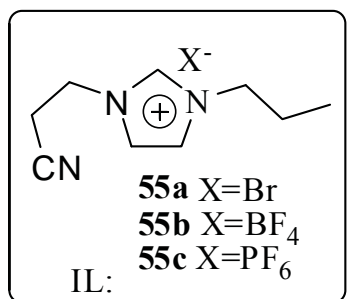

The reaction of carene 1a, with $\mathrm{Ac}_{2} \mathrm{O}$ in the presence of ionic liquid 55a at $50^{\circ} \mathrm{C}$ gave the mixture of $4 \alpha-$ and 4 $\beta$-acetyl-2-carenes 23,54 (ratio 95:5). All the attempts of hydroxymethylation of 1a using paraformaldehyde in the presence or in the solution of ionic-liquids 55a-c have failed. Only the addition of the AcOH to the indicated mixture has contributed to the proceeding of Prins's reaction with the formation of $4 \alpha$-hydroxymethyl-2-carenes 53a,c and $4 \alpha$-acetoxymethyl-2-carenes $\mathbf{5 3 b}$ as well.

The silylation of compound $\mathbf{2 3}$ was carried out in both conditions of kinetic and thermodynamic control of the reaction [130-132]. The reaction of compound 23 with chlorotrimethylsilane afforded silyl enol ether 56a [133,134].

Scheme 24

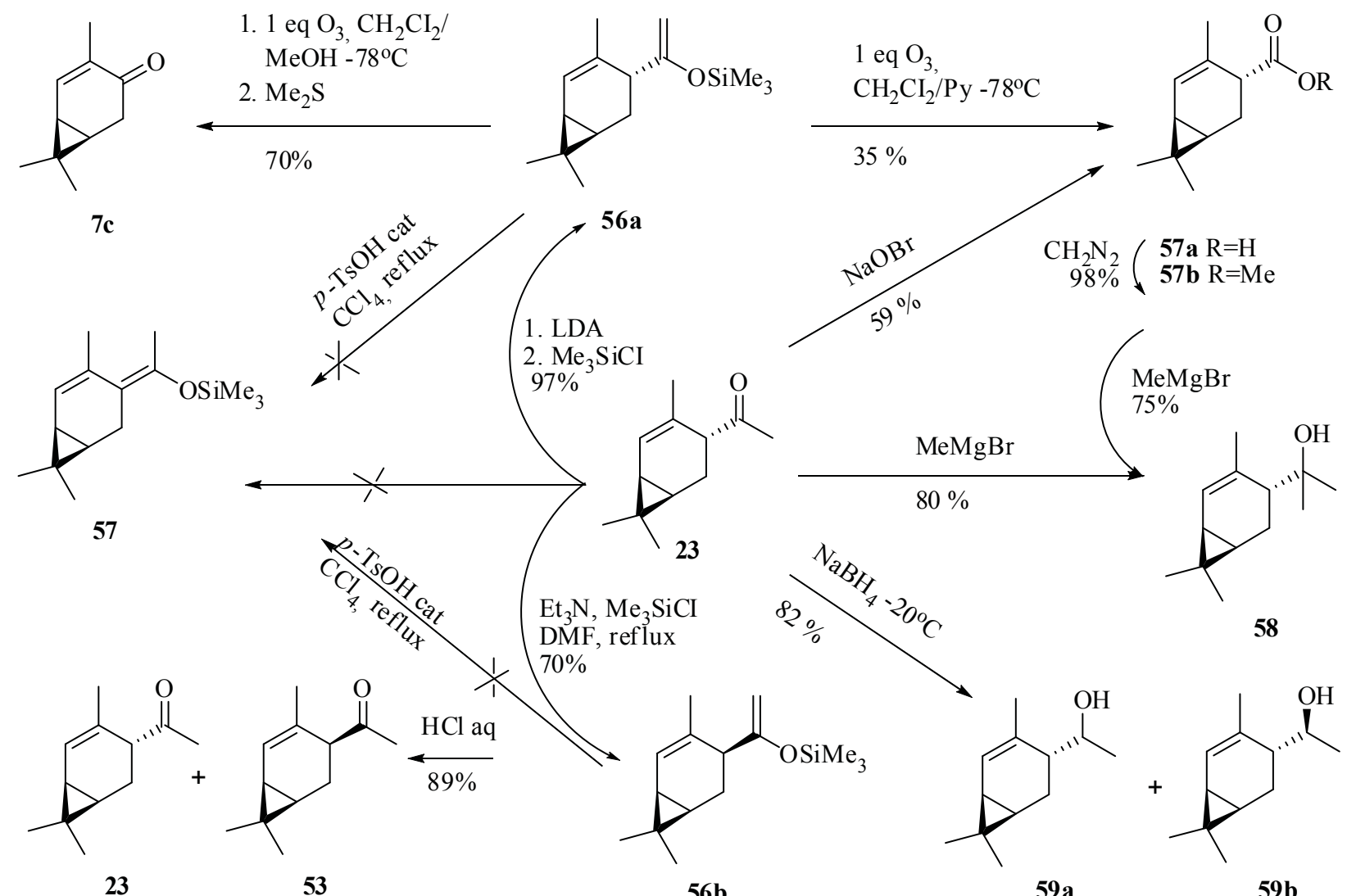

An interaction of ketone $\mathbf{2 3}$ with the mixture of $\mathrm{Et}_{3} \mathrm{~N}$-chlorotrimethylsilane in DMF gave an epimer $\mathbf{5 6} \mathbf{b}$. The attempts to isomerize ethers $\mathbf{5 6} \mathbf{6}, \mathbf{b}$ into isomer $\mathbf{5 7}$ have failed. The product of hydrolysis has represented a 
mixture of $4 \alpha$ - and $4 \beta$-acetyl-2-carenes 23, 53 (ratio 5:95). Ozonolysis of the ether 56a in the mixture of $\mathrm{CH}_{2} \mathrm{Cl}_{2} /$ $\mathrm{MeOH}$ followed by the decomposition of peroxides with $\mathrm{Me}_{2} \mathrm{~S}$ proceeds with the formation of well-known [135-138] car-2-en-4-one 7c. As far as the stability of ethers $\mathbf{5 6} \mathbf{6}, \mathbf{b}$ towards isomerization is concerned, it is most probable that the rearrangement of intermediary products occurs during ozonization. The acid $\mathbf{5 7}$ a has been synthesized from the ketone $\mathbf{2 3}$ in the condition of hypobromide oxidation as well as by ozonolysis of the ether 56a $[139,140]$. The ester 57b or the ketone 23 could react with MeMgBr to give the alcohol 58. Crystalline epimer 59a is easily separated from the oil-like alcohol 59b by the crystallization from hexane [141-143].

To develop new efficient routes to functionalized pyridines, amide 61 was tested as starting chirone [144].

\section{Scheme 25}<smiles>CC1CC(=O)C2C(C1)C2(C)C</smiles>

36<smiles>C[C@@H]1CC(=NO)C2C(C1)C2(C)C</smiles>

60<smiles>CC(=O)NC1=C[C@@H](C)CC2C1C2(C)C</smiles>

61<smiles>C[C@H]1CC(C(C)(C)C=O)=Cc2nc(Cl)ccc21</smiles>

$62(32 \%)$<smiles>CC(C)C1=Cc2nc(Cl)ccc2[C@@H](C)C1</smiles>

$63(31 \%)$<smiles>C[C@@H]1C[C@@H]2c3ccc(Cl)nc3[C@@H]2C1(C)C</smiles>

64

However, the heterocyclisation step leads to the cyclopropane ring opening reaction with the formation of two types of pyridines 62, 63 without target 64. This problem was solved by replacing direct heterocyclisation step with a Krohnke annulation. The exo-methylene functionality was prepared via Claisen condensation followed by transaldolization. The reaction of enone $\mathbf{6 5}$ with Krohnke salt afforded pyridone 66. The treatment of the latter derivative with $\mathrm{POCl}_{3} \mathrm{produced}$ the target chloride $67 \mathbf{a}$ in a modest yield. By contrast, the conversion into the triflate $67 \mathbf{b}$ occurred almost quantitatively. The triflate $\mathbf{6 7} \mathbf{b}$ was then coupled using the $\mathrm{Ni} / \mathrm{Zn}$ to afford the required bis-pyridine $\mathbf{6 8}$.

\section{Scheme 26}<smiles>C=C1C(=O)C2C(C[C@@H](C)C2(C)C)C1(C)CO</smiles>

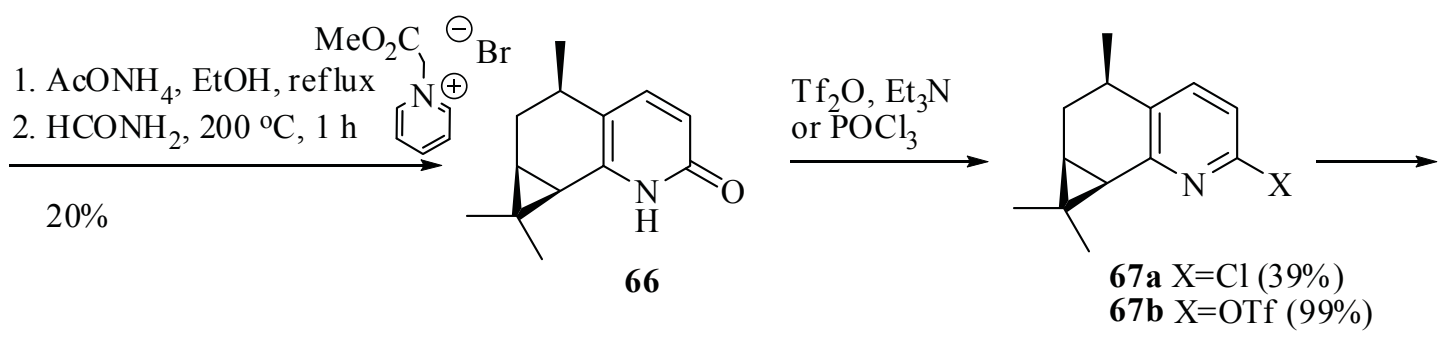

\footnotetext{
$\mathrm{NiCI}_{2}, \mathrm{Zn}, \mathrm{Ph}_{3} \mathrm{P}$

$\mathrm{Me}_{4} \mathrm{NI}, \mathrm{DMF}, 60^{\circ} \mathrm{C}, 24 \mathrm{~h}$

$52 \%$
}<smiles>CC1C2[C@H]1C[C@@H](C)[C@H]1c3ccc(-c4ccc5c(n4)C4C(C[C@H]4C)C5(C)C)nc3[C@H]21</smiles>

68 
A moderate yield of asymmetric allylic oxidation of cycloalkenes catalyzed by $\mathrm{Cu}$-complexes of chiral ligand $\mathbf{5 7}$ was observed.

The synthesis of more functionalized bis-pyridine 69, 70 was realized from the enone $\mathbf{6 5}[145,146]$. The reactions carried out successfully are detailed in scheme 27.<smiles>C=C1C(=O)C2C(C[C@@H]1C)C2(C)C</smiles>

65<smiles>CC(=O)C(C)(C)C(C)=O</smiles>

1. LDA

2. $\mathrm{NH}_{4} \mathrm{OAc}$ $\mathrm{AcOH}$ $8 \%$

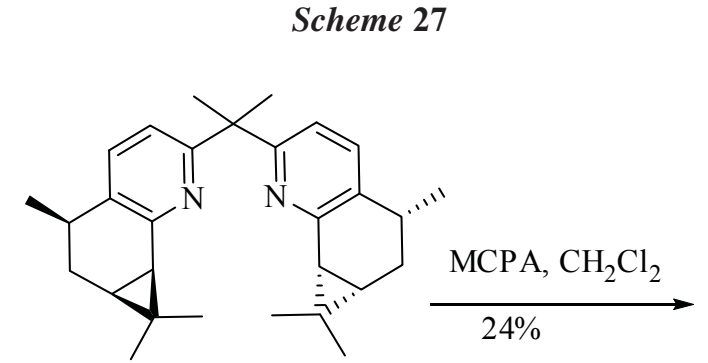

69

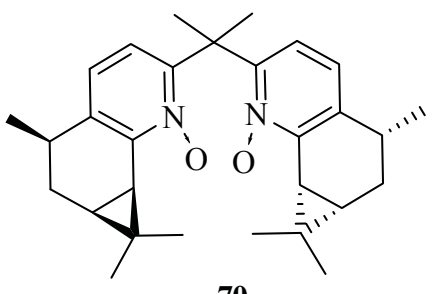

70

The allylation of aldehydes with allyltrichlorosilane promoted by new chiral dipyridylmethane N-oxides 70 was realized with moderate yield (58\%) and good (83\%) enantioselectivity.

Thus, it has been shown that the functionalization of carene's $\pi$-bond with subsequent conversions gives compounds with carane skeleton in the molecule.

\section{Synthesis on the basis of 2-carenes with carane skeleton retention}

As has been mentioned above, the 2-carene $\mathbf{1 b}$ is a convenient initial compound for a purposeful synthesis. A heterogeneous catalyzed isomerization on inorganic materials (zeolites in the basic form, nickel catalysts on $\mathrm{SiO}_{2}$ ) or via hydrogenation of (+)-3-carene 1a was described [147-150]. In all cases the mixture of 1a,b separated with a great difficulty was obtained.

The transformation of $(+)-3$-carene 1a into mixture diethylboranes 72-74 and hydrolysis resulted in the mixture of carenes 1a (yield 9\%), $\mathbf{1 b}$ (yield 9\%) and $\mathbf{7 1}$ (yield 82\%) (scheme 28) [151].

\section{Scheme 28}

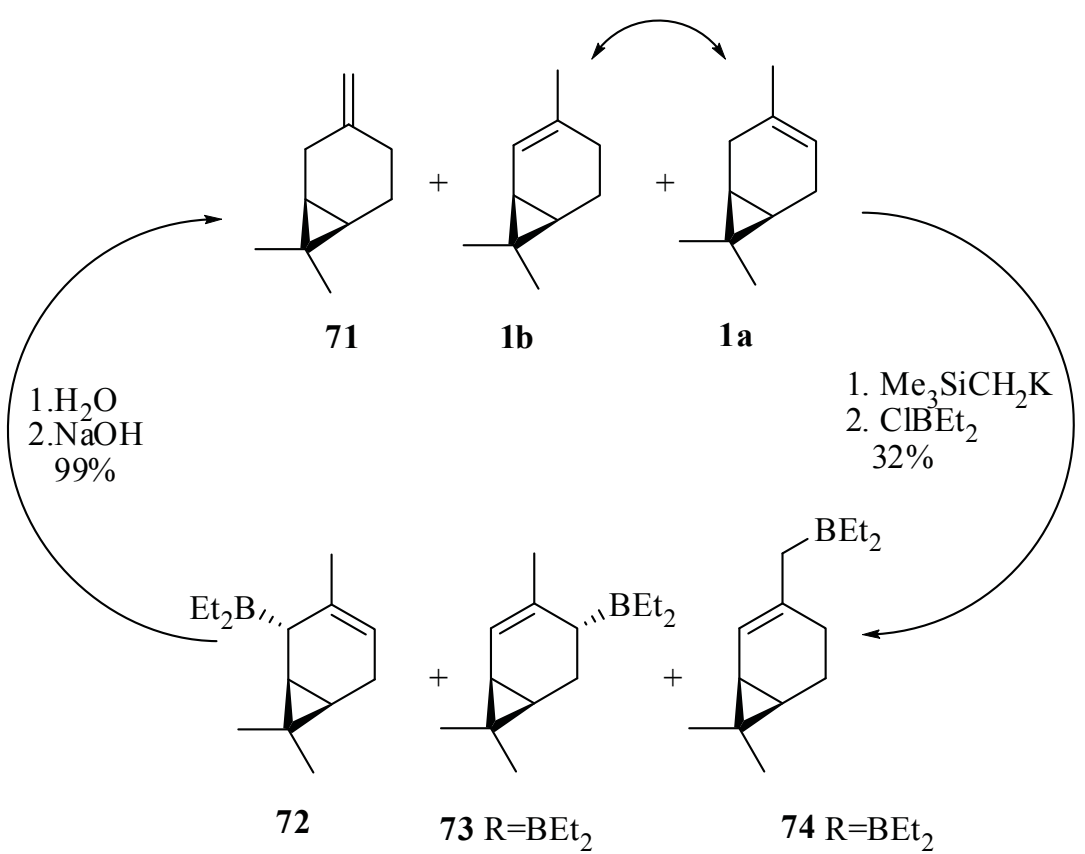

Amino homologues 75, 76 have been synthesized from 2-carene 1b [152, 153].

The initially formed mixture of regioisomeric imides is subjected to [2,3]-sigmatropic rearrangement, and its subsequent hydrolysis leads to a pair of amines 75 (yield 11\%), 76 (yield 5\%). 


\section{Scheme 29}

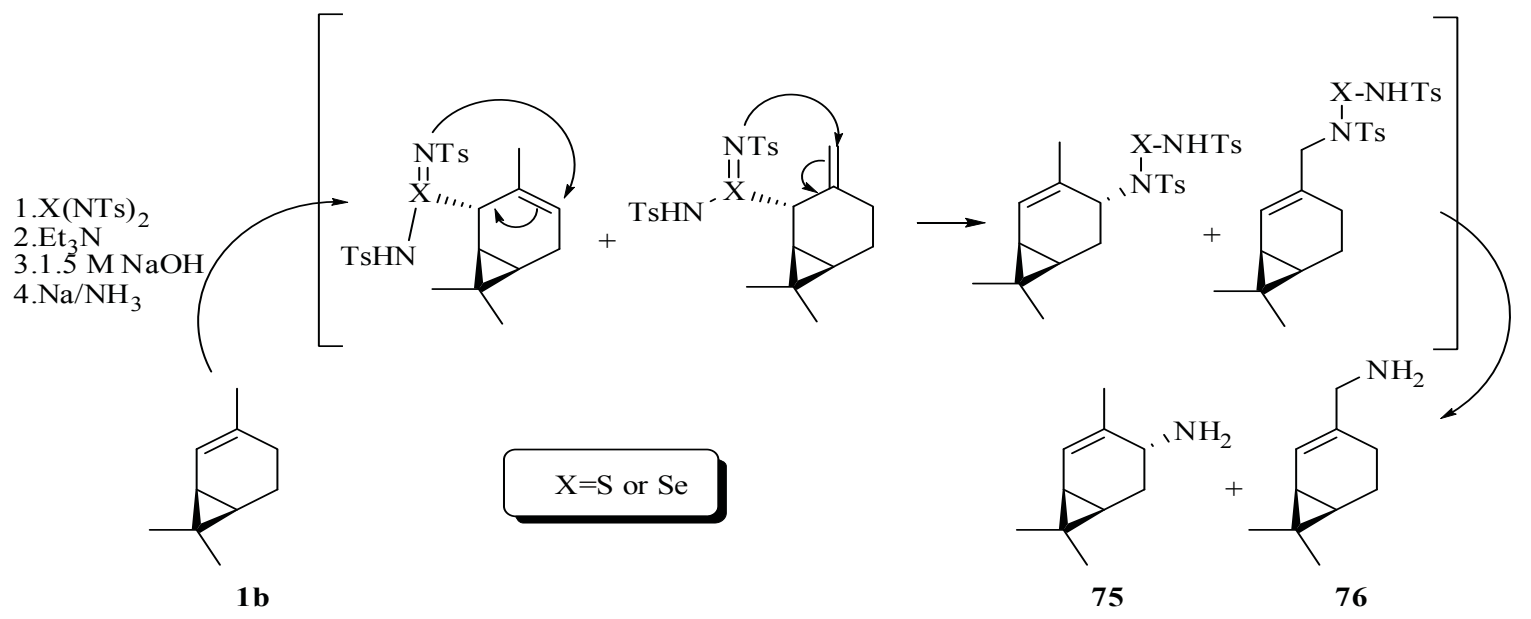
$1 \mathbf{b}[154]$.

Brown and co-workers have proposed a stereocontrolled synthesis of caranol 77a via hydroboration of $(+)-2$-carene

\section{Scheme 30}

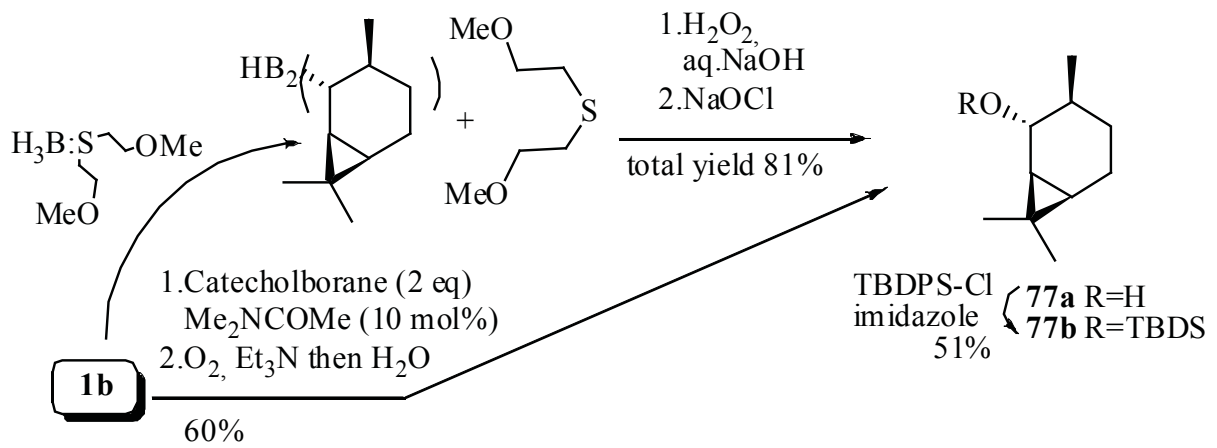

Another group has established that oxygen oxidizes the aryl(alkyl)boronates up to hydroxylated product $\mathbf{7 7 a}$, however this method is less selective [155]. The alcohol is characterized as ether 77b.

A new and readily available modular phosphate ligand 79a with $\mathrm{P}^{*}$-stereocentre has been prepared from caran2,3-diols 78 [60]. The acetals 79b were transformed into chiral intermediates 80a,b and $\mathbf{8 1}$ (scheme 31) [156].

Scheme 31

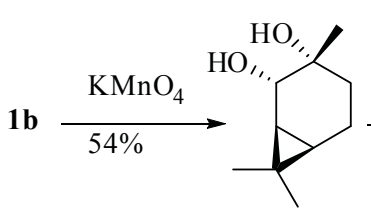

78<smiles>[R1]C1(C)C2CC[C@H](C)[C@H](O[C@@H]3C[C@H](C(=O)OCC)C(C)=NN3C(N)=O)C21</smiles>

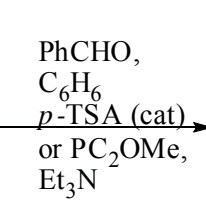

79b $\mathrm{X}=\mathrm{CHPh} \quad(88 \%)$

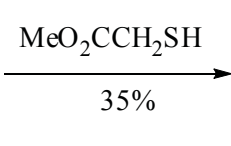$$
\%
$$$$
\%)
$$

(1)

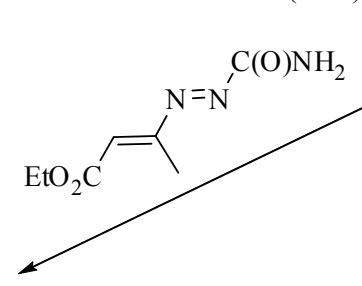<smiles>[R20][C@H]1[C@@H](C)CC[C@@H]2[C@H]1C2(C)C</smiles>

80a $\mathrm{R}=\mathrm{Bn}$ $\mathbf{8 0 b} \mathrm{R}=\mathrm{CH}=\mathrm{CH}_{2}$<smiles>[R20][C@@H]1[C@@H](C)CC[C@H]2[C@H]1C2(C)C</smiles>

$81 \mathrm{R}=\mathrm{Bn}$<smiles>C1CC1</smiles><smiles>N#C/C(=C\c1ccccc1)[N+](=O)[O-]</smiles><smiles></smiles> 
The synthesis of more functionalized ether 82, 83 via two different [4+2] cycloaddition reactions in aqueous medium is presented $[157,158]$.

Bis-pyridine 85 was obtained via an initial transformation of (+)-2-carene 1b into pyridone 84 [144]. The treatment of the latter compound with $\mathrm{Tf}_{2} \mathrm{O}$ following the coupling affords the compound $\mathbf{8 5}$. Asymmetric allylic oxidation of cyclic olefins with good conversion rates and acceptable enantioselectivity (67\% ee) was registered by $\mathrm{Cu}$-complexes of ligand $\mathbf{8 5}$.

\section{Scheme 32}

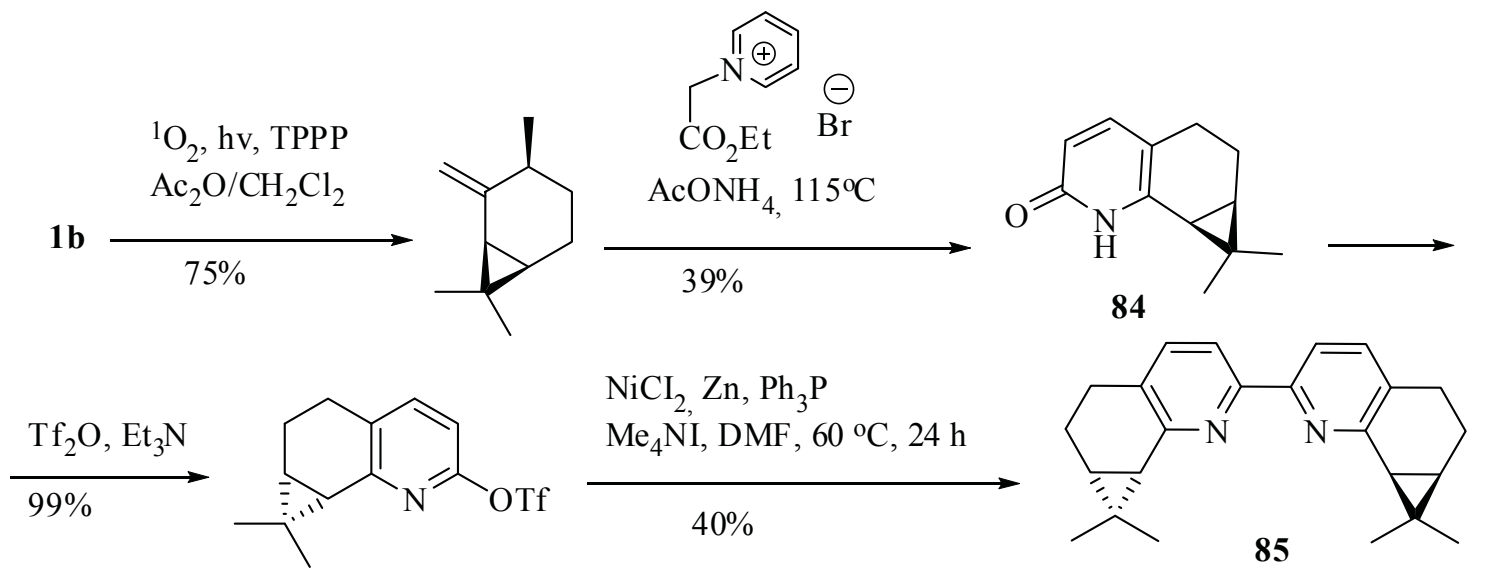

Mixtures of lactams $\mathbf{8 7 ,} 90$ have been obtained by addition to monoterpene $\mathbf{1 b}$ chlorosulfonyl isocyanate [159].

It was reported that isomers $\mathbf{8 7 , 9 0}$ could not be separated in a pure form and significant amounts. Analytically pure samples were isolated after fractional recrystallization from hexane.

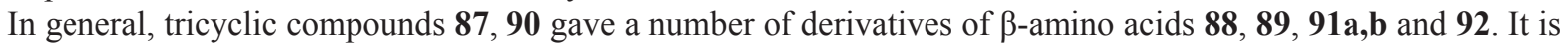
to be noted that, in contrast to amino ester $\mathbf{8 8}$ its region-isomer $\mathbf{9 1 a}$ was readily hydrolyzed to the acid $\mathbf{9 1 b}$ under the $\mathrm{NaOMe}$ catalyzed methanolysis as well as in the presence of even small amounts of water. The mixture of compounds 91a,b can be reduced with a reasonable yield to amino alcohol 92 with $\mathrm{LiAlH}_{4}$.

Scheme 33

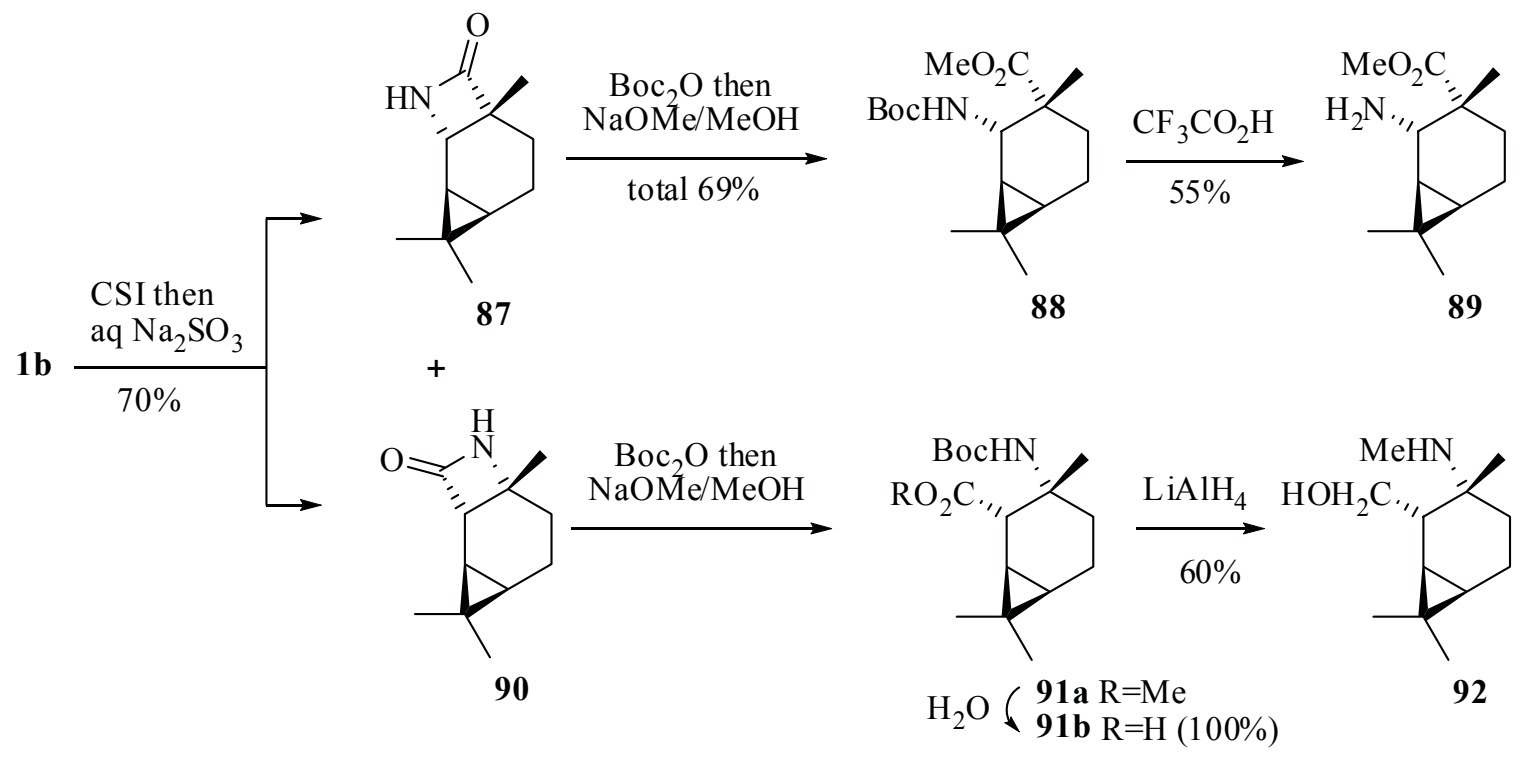

\section{Conclusion}

It is clear from the above relative reactivity data of monoterpenes $(+)-2-$ and $(+)-3$-carenes that there are good posibilities of establishing objective or sets criteria which help decide whether electrophilic addition or dipolar cycloadditions to carbon-carbon double bonds involve the synthesis with the retention of the bicyclic framework. Although the coupling reactions should be optimised and the cyclisation of such compounds has not been attempted, one can rely on the results obtained with the polycyclic compounds. The synthesized compounds can be further converted 
into the substances of known pharmaceutical interest and the obtained molecules can also display interesting biological properties.

In conclusion, it might be stated that the actual details of the transformation of bicyclic monoterpenes employing a stereoselective functionalized of the cyclohexene rings are yet to be clarified on the basis of more definitive studies.

\section{Acknowledgements}

The authors gratefully acknowledge generous financial support from the ASM-MESU bilateral project 01/UA.

\section{References}

[1]. Ho, T.L. Enantioselective Synthesis Natural Products from Chiral Terpenes. NY, Chichester, Brisbane, Toronto, Singapore. John Wiley\&Sons, Inc. 1992, 324 p.

[2]. Ho, T.L. Carbocycle Construction in Terpene Synthesis. Weinheim, NY, Basel, VCH. 1988, 768 p.

[3]. Arlt, D.; Jautelat, M.; Lantzsch, R. Angew. Chem. 1981, 93, 719-840.

[4]. Хусид, А.Х.; Нефедов, О.М. Ж.В.Х.О. 1988, 33, 653-661.

[5]. Фокин, А.А.; Баула, О.П.; Красуцкий, П.А.; Юрченко, А.Г. Укр. Хим. журнал. 1992, 58, 1127-1133.

[6]. Macaev, F.Z.; Malkov, A.V. Tetrahedron. 2006, 62, 9-26.

[7]. Macaev, F. Cercetări în domeniul chimiei; Î.E.P. Ştiința: Chişinău, 1999, 66-92.

[8]. Chuiko V.A., Vyglazov O.G. Russ. Chem. Rev., 2003, 72, 49-67.

[9]. Salakhutdinov, N.F.; Barkhash, V.A. Russ. Chem. Rev., 1997, 66, 343-362.

[10]. Родионов, В.Н.; Козликовский, Я.Б.; Андрущенко, В.А. Ж. Орг. химии. 1991, 27, 2627.

[11]. Половинка, М.П.; Корчагина, Д.В.; Гатилов, Ю.В.; Выглазов, О.Г.; Зенкович, Г.А.; Бархаш, В.А. Ж. Орг. химии. 1998, 34, 342-1349.

[12]. Чуйко, В.А.; Выглазов, О.Г.; Тычинская, Л.Ю. Ж. Орг. химии. 1998, 34, 1357-1362.

[13]. Ильина, И.В.; Волчо, К.П.; Корчагина, Д.В.; Салахутдинов, Н.Ф.; Бархаш, В.А. Ж. Орг. химии. 1999, 35 , 699-710.

[14]. Халиулин, Р.Р.; Племенков, В.В. Ж.Общ. химии. 1993, 63, с. 874-879.

[15]. Федюнина, И.В.; Никитина, Л.Е.; Племенков, В.В. Химия природ. соедин. 1993, 5, 677-684.

[16]. Федюнина, И.В.; Племенков, В.В., Никитина, Л.Е.; Литвинов, И.А.; Катаева, О.Н. Химия природ. соедин. 1995, 4, 576-580.

[17]. Kluge, R.; Schulz, M.; Liebsch, S. Tetrahedron. 1996, 52, 2957-2976.

[18]. Khanra, A.S.; Chakravarti, R.K.; Mitra, R.B. Indian J. Chem.1975, 13, 314-317.

[19]. Mane, B.M.; Gore, K.G.; Kulkarni, G.H. Indian J. Chem.1980, 19B, 605-607.

[20]. Bach, R.D.; Klin, M.W.; Ryntz, R.A.; Holbuka, J.W. J. Org. Chem. 1979, 44, 2569-2571.

[21]. Mitra, R.B.; Mulyiami, Z.; Deshmukh, A.R.A.S.; Joshi, V.S.; Garde, S.A. Synth. Commun. 1984, 14, $101-112$.

[22]. Punniyamurthy, T.; Velusamy, S.; Iqbal, J. Chem. Rev., 2005, 105, 2329-2363.

[23]. Grigoropoulou, G.; Clark, J.H. Tetrahedron Letters, 2006, 47, 4461-4463.

[24]. Santos, I.C.M.S.; Rebelo, S.L.H.; Balula, M.S.S.; Martins, R.R.L.; Pereira, M.M.M.S.; Simoes, M.M.Q.; Neves, M.G.P.M.S.; Cavaliero, J.A.S,; Cavaliero, A.M.V. Journal of Molecular Catalysis A: Chemical, 2005, 231, 3545.

[25]. Bordoloi, A.; Lefebvre, F.; Halligudi, S.B. Journal of Molecular Catalysis A: Chemical, 2007, 270, $177-184$.

[26]. Saladino, R.; Andreoni, A.; Neri, V.; Crestini, C. Tetrahedron, 2005, 61, 1069-1075.

[27]. Nardello, V.; Aubry, J.M.; De Vos, D.E.; Neumann, R.; Adam, W.; Zhang, R.; Ten Elshof, J.E.; Witte, P.T.; Alsters, P.L. Journal of Molecular Catalysis A: Chemical, 2006, 251, 185-193.

[28]. Rebelo, S.L.H.; Goncalves, A.R.; Pereira, M.M.; Simoes, M.M.Q.; Neves, M.G.P.M.S.; Cavaliero, J.A.S. Journal of Molecular Catalysis A: Chemical, 2006, 256, 321-323.

[29]. Santos I.C.M.S.; Simões, M.M.Q.; Pereira, M.M.M.S.; Martins, R.R.L.; Neves, M.G.P.M.S.; Cavaleiro, J.A.S., Cavaleiro, A.M. V. Journal of Molecular Catalysis A: Chemical, 2003, 195, 253-262.

[30]. Martins, R.R.L.; Neves, M.G.P.M.S.; Silvestre, A.J.D.; Simões, M.M.Q.; Silva, A.M.S.; Tomé, A.C.; Cavaleiro, J.A.S.; Tagliatesta, P.; Crestini, C. Journal of Molecular Catalysis A: Chemical. 2001, 172, 33-42.

[31]. Krishnaswamy, D.; Bhawal, B.M.; Deshmukh, A.R.A.S. Tetrahedron Lett., 2000, 41, 417-420.

[32]. Krishnaswamy, D.; Govande, V.V.; Gumaste, V.K.; Bhawal, B.M.; Deshmukh, A.R.A.S. Tetrahedron, 2002, 58, 2215-2225.

[33]. Asouti, A.; Hadjiarapoglou, L. Synlett, 2001, 12, 1847-1850.

[34]. Van Vliet, M.C.A.; Arends, I.W.C.E.; Sheldon, R.A. Synlett, 2001, 1305-1307.

[35]. Saladino, R.; Neri, V.; Pelliccia, A.R.; Mincione, E. Tetrahedron, 2003, 59, 2403-2407.

[36]. Shaha, S.C.; Joshi, G.D.; Pai, P.P.; Deshmukh, A.R.A.S.; Kulkarni, G.H. Chem. Ind. 1989, $17,568$. 
[37]. Kauffman, G.S.; Harris, G.D.; Dorow, R.L.; Stone, B.R.P.; Parsons, R.L.; Pesti, J.A.; Magnus, N.A.; Fortunak, J.M.; Confalone, P.N.; Nugent, W.A. Org. Lett. 2000, 2, 3119-3122.

[38]. Santos, I.C.M.S.; Simoes, M.M.Q.; Pereira, M.M.M.S.; Martins, R.R.L.; Neves, M.G.P.M.S.; Cavaleiro, J.A.S.; Cavaliero, A.M.V. Journal of Molecular Catalysis A: Chemical. 2003, 195, 253-262.

[39]. Martins, R.R.L.; Neves, M.G.P.M.S.; Silvestre, A.J.D.; Simoes, M.M.Q.; Silvia, A.M.S.; Tome, A.C.; Cavaleiro, J.A.S.; Tagliatesta, P.; Crestini, C. Journal of Molecular Catalysis A: Chemical. 2001, 172, 33-42.

[40]. Mitra, R.B.; Muljiani, Z.; Deshmukh, V.S.; Joshi, V.S.; Gadre, S.R. Synth. Commun. 1984, 14, $101-112$.

[41]. Krishnaswamy, D.; Bhawal, B.M.; Deshmukh, A.R.A.S. Tetrahedron Lett. 2000, 41, 417-420.

[42]. Krishnaswamy, D.; Govande, V.V.; Gumaste, V.K.; Bhawal, B.M.; Deshmukh, A.R.A.S. Tetrahedron. 2002, 58, 2215-2225.

[43]. Asouti, A.; Hadjiarapoglou, L. Synlett. 2001, 12, 1847-1850.

[44]. Kluge, R.; Schulz, M.; Liebsch, S. Tetrahedron. 1996, 52, 2957-2976.

[45]. Reddy, M.M.; Punniyamurhty, T.; Iqbal, J. Tetrahedron Lett. 1995, 36, 159-162.

[46]. Kende, A.S.; Delair, P.; Blass, B.E. Tetrahedron Lett. 1994, 35, 8123-8126.

[47]. Kolehmainen, E.; Laihia, K.; Heinänen, M.; Rissanen, K.; Frönlich, R.; Korvola, J.; Mänttäri, P.; Kauppinen, R. J. Chem. Soc., Perkin Trans. 2. 1993, 641-648.

[48]. Van Vliet, M.C.A.; Arends, I.W.C.E.; Sheldon, R.A. Synlett. 2001, 1305-1307.

[49]. Saladino, R.; Neri, V.; Pelliccia, A.R.; Mincione, E. Tetrahedron. 2003, V. 59, № 14, p. 2403-2407.

[50]. Nardello, V.; Aubry, J.M.; De Vos, D.E.; Neumann, R.; Adam, W.; Zhang, R.; Ten Elshof, J.E.; Witte, P.T.; Alsters, P.L. Journal of Molecular Catalysis A: Chemical. 2006, 251, 185-193.

[51]. Rajan, V.P.; Bannore, S.V.; Subbarao, H.N.; Dev, S. Tetrahedron. 1984, 40, 983-990.

[52]. Cocker, W.; Grayson, D.H. Tetrahedron Lett. 1969, 10, 4451-4452.

[53]. Никитина, Л.Е.; Старцева, В.А.; Дорофеева, Л.Ю.; Артемова, Н.П.; Кузнецов, И.В.; Лисовская, С.А.; Глушко, Н.П. Химия природ. соедин., 2010, 1, 17-30.

[54]. Артемова, Н.П.; Бикбулатова, Г.Ш.; Племенков, В.В.; Ефремов, Ю.Я. Ж. Общ. химии.1991, 61, 14841485 .

[55]. Артемова, Н.П.; Бикбулатова, Г.Ш.; Племенков, В.В.; Наумов, В.А.; Катаева, О.Н. Химия природ. соед. 1991, 2, 193-198.

[56]. Hendrich, A.; Piatkowski, K. Polish Journal of Chemistry. 1984, 58, 73-84.

[57]. Gomes, M.; Antunes, O.A.C. Catalysis Commun. 2001, 2, 225-227.

[58]. Волчо, К.П.; Татарова, Л.Е.; Корчагина, Д.В.; Салахутдинов, Н.Ф.; Бархаш, В.А. Ж. Орг. химии. 2000, 36, 41-48.

[59]. Gavrilov, K.N.; Benetsky, E.B.; Grishina, T.B.; Zheglov, S.V.; Rastorguev, E.A.; Petrovskii, P.V.; Macaev, F.Z.; Davankov, V.A. Tetrahedron: Asymmetry. 2007, 18, 2557-2564.

[60]. Benetsky, E.B.; Zheglov, S.V.; Grishina, T.B.; Macaev, F.Z.; Bet, L.P.; Davankov, V.A.; Gavrilov, K.N. Tetrahedron Lett. 2007, 48, 8326-8330.

[61]. Joshi, S.N.; Malhotra, S.V. Tetrahedron: Asymmetry, 2003, 14, 1763-1766.

[62]. Kauffman, G.S.; Harris, G.D.; Dorow, R.L.; Stone, B.R.P.; Parsons, R.L.; Pesti, J.A.; Magnus, N.A.; Fortunak, J.M.; Confalone, P.N.; Nugent, W.A. Organic Lett., 2000, 2, 3119-3121.

[63]. Parsons, R.L.; Fortunak, J.M.; Dorow, R.L.; Harris, G.D.; Kauffman, G.S.; Nugent, W.A. J. Am. Chem. Soc., 2001, 123, 9135-9143.

[64]. Fedunina, I.V.; Plemenkov, V.V.; Bikbulatova, G.Sh.; Nikitina, L. E.; Litvinov, I. A.; Kataeva, O.N. Chem. Natur. Compds. 1992, 2, 203-208.

[65]. Isaeva, Z.G.; Bakaleinik, G.A. Izvestia Akademii Nauk SSSR. Seriya Khimicheskaya. 1985, 3, 648-653.

[66]. Kazakova, E.Kh.; Davletshina, G.R.; Bakaleinik, G.A.; Vereshagin, A.N. Izvestia Akademii Nauk SSSR. Seriya Khim. 1986, 4, 842-846.

[67]. Исаева, 3.Г.; Андреева, И.С. Докл. АН СССР. 1963, 152, 106-109.

[68]. Satoh Tsuyoshi; Okuda Teruyoshi; Kaneko Youhei. Chem. Pharm. Bull. 1984, 32, 1401-1410.

[69]. Shagidullin, R.R.; Isaeva, Z.G.; Povodyreva, I.P.; D’yakonova, R.R. Doklady Akademii Nauk. 1972, 202, 13491351 .

[70]. Krasutskii, P.A.; Fokin, A.A.; Gulevich, A.V.; Yurchenko, A.G.; Promonenkov, V.K. Russ. J. Org. Chem. 1992, 28, 1098-1099.

[71]. Kazakova, E.Kh.; Davletshina. G.R.; Vereshagin, A.N. Izvestia Akademii Nauk SSSR. Seriya Khim. 1986, V. 4, p. 842-846.

[72]. Arbuzov, B.A.; Ibragimova, N.D.; Povodyreva, I.P. Izvestia Akademii Nauk SSSR. Seriya Khim. 1980, 10521054.

[73]. Isaeva, Z.G.; Bikbulatova, G.Sh.; Podvodyreva, I.P. Izvestia Akademii Nauk SSSR. Seriya Khimicheskaya. $1979,5,1107-1110$. 
[74]. Sonawane, H.R.; Nanjundiah, B.S.; Purohit, P.C. Tetrahedron Lett., 1983, 24, 3917-3918.

[75]. Carson, M.S.; Cocker, W.; Grayson, D.H.; Shannon, P.V.R. J. Chem. Soc. C. 1969, 2220-2228.

[76]. Kropp, P.J. J. Am. Chem. Soc. 1966, 88, 4926-4934.

[77]. Chabudzinski, Z.; Kuczynski, H. Roczniki chimii. Ann.Soc.Chim. Polonorum. 1962, 36, 1173-1181.

[78]. Толстиков, Г.А.; Галин, Ф.З.; Игнатюк, В.К.; Кашина, Ю.А.; Галкин, Е.Г. Журн. орг. химии. 1995, 31, 1149-1151.

[79]. Tolstikov, G.A.; Galin, F.Z.; Ignatyuk, V.K.; Kashina, Yu.A.; Zelenova, L.M. Chemistry of Natural Compounds. 1992, 22, 295-297.

[80]. Reddy, M.M.; Punniyamurthy, T.; Iqbal, J. Tetrahedron Lett., 1995, 36, 159-162.

[81]. Ohloff, G. Scent and fragrances. The fascination of odors and their chemical perspectivies. Berlin, Heidelberg, NY, London, Paris, Tokyo, Hong Kong, Barselona, Budapest. Springer-Verlag. 1994, 240 p.

[82]. Muller, P.M.; Lamparsky, D. Perfumes. Art, Science and Technology. London, Glasgow, NY, Tokyo, Melbourne, Madras. Blackie Academic\&Professional. 1991, 661 p.

[83]. Шулов Л.М., Хейфиц Л.А. Душистые вещества и полупродукты парфюмерно-косметического производства. Москва, Агропромиздат. 1990, 208 с.

[84]. Хейфиц Л.А., Дашунин В.М. Душистые вещества и другие продукты парфюмерии. Москва, Химия. 1994, 256 c.

[85]. Silva, J.G.; Barros, H.J.V.; Balanta, A.; Bolaños, A.; Novoa, M.L.; Reyes, M.; Contreras, R.; Bayón, J.C.; Gusevskaya, E.V.; Santos, E.N. Applied Catalysis A: General. 2007, 326, 219-226.

[86]. Narasimhan, S.; Ramesha, A.R. Indian Journal of Chemistry, 1992, 31B, 645-647.

[87]. Hendrich, A.; Piatkowski, K.; Gora, J. Perfumer\&Flavorist. 1986, 11, 85-88.

[88]. Арбузов, Б.А.; Исаева, З.Г.; Поводырева, И.П.; Ратнер, В.В. Изв. АН СССР. Сер. Хим. 1979, 10, 22312234.

[89]. Арбузов, Б.А.; Ратнер, В.В.; Исаева, З.Г.; Гудова, В.Н., Рубинова, Н.Р.; Беляева, М.Г. Изв. АН СССР. Сер. Хим. 1979, 6, 1294-1298.

[90]. Lochynski, S.; Kowalska, K.; Wawrzenczyk, C. Flavour and Fragrance Journal. 2002, 17, 181-190.

[91]. Lochynski, S.; Frackowiak, B.; Olejniczak, T.; Ciunik, Z.; Wawrzenczyk, C. Tetrahedron: Asymmetry. 2002, 13, 1761-1767.

[92]. Sekine, A.; Kumagai, N.; Uotsu, K.; Ohshima, T.; Shibasaki, M. Tetrahedron Lett. 2000, 41, 509-513.

[93]. Mühlstädt, M.; Richter, P. Chem. Ber. 1967, Bd 100, 1892-1897.

[94]. Gollnick, K.; Schade, G.Tetrahedron. 1966, 22, 133-137.

[95]. Borowiecki, L.; Zacharewicz. Rocziki Chem. 1963, 37, 1143-1149.

[96]. Brown, H.C.; Garg, C.P. J.Am.Chem.Soc. 1961, 83, 2952-2953.

[97]. Lajuenen, M. Tetrahedron. 1994, 50, 13181-13198.

[98]. Фокин, А.А.; Бутова, Е.Д.; Коломицин, И.В.; Гагаева, Е.А.; Гогоман, И.В.; Корнилов, А.М.; Сорочинский, А.Е.; Юрченко, А.Г.; Красуцкий, П.А. Орг. химии. 1994, 30, 669-679.

[99]. Fletcher, R.J.; Motherwell, W.B.; Popkin, M.E. Chem. Commun. 1998, 20, 2191-2192.

[100]. Krepinsky, J.; Jommi, G.; Samek, Z.; Sorm, F. Coll. Čzech. Chem. Commun. 1970, 35, 745-748.

[101]. Barlow, F. Pest. Sci. 1971, 2, 115-118.

[102]. Мельников, Н.Н. Пестициды. 1987, Москва, Химия, 712 с.

[103]. Elliot, M. Nature. 1973, 244, 546-547.

[104]. Motherwell, W.B.; Bégis, G.; Cladingboel, D.E.; Jerome, L.; Sheppard, T.D. Tetrahedron, 2007, 63, 64626476.

[105]. Fletcher, R.J.; Motherwell, W.B.; Popkin, M.E. Chem. Commun., 1998, 20, 2191-2192.

[106]. Motherwell, W.B.; Roberts, L.R. Tetrahedron Lett., 1995, 36, 1121-1124.

[107]. Makaev, F. Z.; Vlad, L. A.; Bets, L. P.; Malinovskii, S. T.; Gavrilov, K. N.; Gdanets, M. Chemistry of Natural Compounds, 2010, 46, 528-533.

[108]. Gyonfalvi, S.; Szakonyi, Z.; Fulop, F..Tetrahedron: Asymmetry. 2003, 14, 3965-3972.

[109]. Srirajan, V.; Deshmukh, A.R.A.S.; Bhawal, B.M. Tetrahedron. 1996, 52, 5585-5590.

[110]. Joshi, S.N.; Deshmukh, A.R.A.S.; Bhawal, M.B. Tetrahedron: Asymmetry. 2000, 11, 1477-1485.

[111]. Joshi, S.N.; Puranik, V.G.; Deshmukh, A.R.A.S.; Bhawal, B.M.. Tetrahedron: Asymmetry. 2001, 12, 30733076.

[112]. Irako, N.; Hamada, Y.; Shioiri, T. Tetrahedron. 1995, 51, 12731-12744.

[113]. Malkov, A.V.; Bella, M.; Stara, I.G.; Kocovsky, P. Tetrahedron Lett. 2001, 42, 3045-3048.

[114]. Kawai, T.; Ooi, T.; Kusumi, T. Chem. Pharm. Bull. 2003, 51, 291-294.

[115]. Malkov, A.V.; Pernazza, D.; Bell, M.; Bella, M.; Massa, A.; Teply, F.; Meghani, P.; Kocovsky, P. J. Org. Chem. 2003, 68, 4727-4742.

[116]. Petukhov, P.; Tkachev, A. Tetrahedron. 1997, 53, 9761-9768. 
[117]. Tkachev, A.V.; Petukhov, P.A.; Konchenko, S.N.; Korenev, S.V.; Fedotov, M.A.; Gatilov, Y.V.; Rybalova, T.V.; Kholdeeva, O.A. Tetrahedron: Asymmetry. 1995, 6, 115-122.

[118]. Lochynski, S.; Kuldo, J.; Frackowiak, B.; Holband, J.; Wojcik, G. Tetrahedron: Asymmetry. 2000, 11, 12951302.

[119]. Muljiani, Z.; Deshmukh, A.R.A.S.; Garde, S.R.; Joshi, V. Synth. Commun. 1987, 17, 25-32.

[120]. Petukhov, P.A.; Tkachev, A.V. Mendeleev Commun. 1996, 2, 64-66.

[121]. Roy, C. D.; Brown, H.C. Tetrahedron: Asymmetry, 2006, 17, 1931-1936.

[122]. Scianowski, J.; Rafinski, Z.; Wojtczak, A.; Burczynski, K. Tetrahedron: Asymmetry, 2009, 20, $2871-2879$.

[123]. Tiecco, M.; Testaferri, L.; Santi, C.; Tomassini, C.; Santoro, S.; Marini, F.; Bagnoli, L.; Temperini, A. Tetrahedron, 2007, 63, 12374-12378.

[124]. Laczkowski, K.Z.; Kmieciak, A.; Kozakiewicz, A. Tetrahedron: Asymmetry, 2009, 20, 1487-1492.

[125]. Macaev, F.; Munteanu, V.; Styngach, E.; Barba, A.; Pogrebnoi, S. Chem. J. Mold., 2007, 2, 119-122.

[126]. Şargorovschi, V.; Styngach, E.; Chem. J. Mold., 2008, 3, 95-97.

[127]. Sargorovschi V., Sucman N., Iudin T., Duca D., Stingaci E., Prodius D., Pogrebnoi S., Macaev F.. Chem. J. Mold., 2010, 5, 36-56.

[128]. Sargorovschi, V.; Sucman, N.; Iudin, T.; Stingaci, E.; Macaev, F. Chem. J. Mold., 2010, 5, 109-117.

[129]. Macaev, F.; Gavrilov, K.; Munteanu, V.; Stingaci, E.; Vlad, L.; Bet, L.; Pogrebnoi, S.; Barba, A. Chem. Nat. Comp. 2007, 43, 136-139.

[130]. Brownbridge, P. Synthesis. 1983, № 1, p. 1-28.

[131]. Brownbridge, P. Synthesis. 1983, № 2, p. 85-104.

[132]. House, H.O.; Czuba, L.G.; Call, M.; Olmstead, H.D. J.Org.Chem. 1969, 34, 2324-2336.

[133]. Макаев, Ф.З.; Галин, Ф.З.; Толстиков, Г.А. Известия РАН, Сер. хим., 1995, 2, 305-309.

[134]. Макаев, Ф.З. Известия РАН, Сер. хим. 2000, 8, 1480-1481.

[135]. Newman, A.A. Chemistry of Terpenes and Terpenoids. London, NY, Academic Press, 1972, 450 p.

[136]. Shastri, M.H.; Patil, D.G.; Patil, V.D.; Dev, S. Tetrahedron. 1985, 41, 3083-3090.

[137]. Jochynski, S.; Jarosz, P.; Wolkowiez, M.; Piatkovski, K. J. Pract. Chimie. 1988, 330, 284-288.

[138]. Khaura, A.S.; Mitra, R.B. Indian J.Chem. 1976, 14B, 716-718.

[139]. Галин, Ф.З.; Макаев, Ф.З.; Толстиков, Г.А. Конференция посвященной 70-летию со дня рождения академика В.А. Коптюга “Современные проблемы органической химии”. Новосибирск, 2001, 51.

[140]. Bet, L.; Vlad, L.; Pogrebnoi, S.; Barba, A.; Macaev, F. The $1^{\text {st }}$ International Conference of the Moldavian Chemical Society. Chisinau, Moldova. 2003, 153.

[141]. Макаев, Ф.3.; Бец, Л.; Влад, Л.; Погребной, С.И.; Галин, Ф.3.; Касрадзе, В. Материалы Российской конференции «Химия и медицина» В книге «Проблемы создания новых лекарственных средств». Гилем, Уфа, Россия, 2003, 72.

[142]. Бец, Л. Cercetări în domeniul chimiei Realizări şi perspective. Chişinău, Î.E.P. Ştiinţa. 2003, II, 93-95.

[143]. Макаев, Ф.; Бец, Л.; Влад, Л.; Погребной, С.; Барба, А.; Бесолов, А.; Малиновский, В.; Любодарский, Р. Ж. Орг. химии. 2006, 42, 872-876.

[144]. Malkov, A. V.; Pernazza, D.; Bell, M.; Bella, M.; Massa, A.; Teply, F.; Meghani, P.; Kocovsky, P. J. Org. Chem., 2003, 68, 4727-4742.

[145]. Chelucci, G.; Baldino, S.; Pinna, G. A.; Benaglia, M.; Buffa, L., Guizzetti S. Tetrahedron, 2008, 64, 75747582.

[146]. Chelucci, G.; Chelucci, G.; Belmonte, N.; Benaglia, M.; Pignataro, L. Tetrahedron Letters, 2007, 48, 40374041.

[147]. Ohloff, G.; Schulte-Elte, K.H.; Giersch, W. Helv. Chim. Acta. 1965, 48, 1665-1668.

[148]. Cocker, W.; Shannon, P.V.R.; Staniland, P.A. J. Chem. Soc. 1966, № 1, p. 41-47.

[149]. Meyer, U.; Hoelderich, W.F.; Journal of Molecular Catalysis A: Chemical. 1999, 142, 213-222.

[150]. Lesage, P.; Candy, J.P.; Hirigoyen, C.; Humblot, F.; Loconte, M.; Basset, J.M. Journal of Molecular Catalysis A: Chemical. 1996, 112, 303-309.

[151]. Zaidlewicz, M.; Giminska, M. Tetrahedron: Asymmetry. 1997, 8, 3847-3850.

[152]. Wyzlic, I.; Uzarewicz, A. Polish J.Chem. 1991, 65, 1999-2004.

[153]. Uzarewicz, A.; Scianowski J. Polish J.Chem., 1997, 71, 48-58.

[154]. Zaidlewicz, M.; Kanth, J.V.B.; Brown, H.C. J.Org.Chem. 2000, 65, 6697-6702.

[155]. Cadot, C.; Dalko, P.; Cossy, J.; Olliver, C.; Chuard, R.; Renaud, P. J.Org.Chem. 2002, 67, 7193-7202.

[156]. Dang, H.S.; Roberts, B.P.; Tocher, D.A. Organic \& Biomolecular Chemistry. 2000, 31, 4073-4084.

[157]. Fringuelli, F.; Matteucci, M.; Piermatti, O.; Pizzo, F.; Burla, M.C. J. Org. Chem. 2001, 66, 4661-4666.

[158]. Attanasi, O.A.; De Crescentini, L.; Flippone, P.; Fringuelli, F.; Mantellini, F.; Matteucci, M.; Piermatti, O.; Pizzo, F. Helv. Chim. Acta. 2001, 84, 513-525.

[159]. Koneva, E.A.; Volcho, K.P.; Gatilov, Y.V.; Korchagina, D.V.; Salnikov, G.E.; Salakhutdinov, N.F. Helvetica Chimica Acta, 2008, 91, 1849-1856. 